\title{
LOTNICZY SKANING LASEROWY W POLSKIEJ ARCHEOLOGII. CZY W PEŁNI WYKORZYSTYWANY JEST POTENCJAŁ PROSPEKCYJNY METODY?*
}

\author{
AIRBORNE LASER SCANNING WITHIN POLISH \\ ARCHAEOLOGY. \\ IS THE METHOD'S POTENTIAL BEING FULLY EXPLOITED?
}

\author{
Łukasz Banaszek \\ Instytut Prahistorii, Uniwersytet im. Adama Mickiewicza \\ ul. Św. Marcin 78, 61-809 Poznań, Poland
}

\begin{abstract}
Airborne Laser Scanning (ALS) is an advanced method of archaeological prospection. One can easily spot an increasing number of applications of LiDAR data within Polish archaeology. Due to that fact it is important to understand the prospective potential of the method as well as subjective character of generated information. The aim of this paper is to describe analytical and interpretative aspects of ALS. Application of LiDAR data is characterised by various processes which lead to the reduction of information about the past. Those processes will be identified and a number of practical solutions aiming to prevent them will be presented. The paper, based on a critical analysis of the procedure of data acquisition and processing as well as creation of the final products, shows how important is knowledge of subjective character of data, tools and techniques during usage of ALS for archaeological purposes.
\end{abstract}

Minęło 6 lat od pierwszego wykorzystania lotniczego skaningu laserowego (ang. Airborne Laser Scanning - ALS) w archeologii ziem polskich ${ }^{1}$. Po trudnych począt-

\footnotetext{
${ }^{*}$ Niniejszy artykuł jest efektem dwóch projektów badawczych: Przeszłe krajobrazy w kontekście danych przestrzennych. Wspótczesne technologie i możliwości interpretacyjne archeologii w studiach mikroregionu wczesnośredniowiecznego grodziska we Wrześnicy, finansowanego przez Narodowe Centrum Nauki (N N109 106 140), oraz Archeologia w lesie. Wykorzystanie GIS i LiDAR w prospekcji archeologicznej na terenie gminy Polanów, realizowanego ze środków Fundacji im. Anny Pasek (2012/1).

${ }^{1}$ Referat J. Nowakowskiego Airborne Laser Scanning (ALS) w polskiej archeologii. Próby, doświadczenia, wyniki podczas XIX Konferencji Sprawozdawczej „Badania archeologiczne na Nizinie Wielkopolsko-Kujawskiej w latach 2008-2009”, Poznań, 26-27.04.2010.
} 
kach aplikacji ALS-u w badaniach nad przeszłością, ta metoda poboru danych przestrzennych, oparta na technologii LiDAR (ang. Light Detection and Ranging), staje się popularna wśród badaczy w Polsce, o czym świadczą zrealizowane lub obecnie prowadzone projekty. Wpływ na rozwój tego zainteresowania miały i wciąż mają następujące czynniki:

- prospekcyjny potencjał metody, niespotykany dotychczas w badaniach krajobrazowych/mikroregionalnych, zwłaszcza obszarów zalesionych;

- spektakularne odkrycia dokonane na podstawie interpretacji wyników skaningu;

- powszechność wykorzystania w archeologii europejskiej;

- działania marketingowe firm geodezyjnych, oferujących usługi skanowania.

Dane lidarowe $^{2} \mathrm{w}$ archeologii znajdują zastosowanie na dwóch poziomach. $\mathrm{Na}$ pierwszym, na podstawie ich analizy i interpretacji, możliwe jest rozpoznanie nieznanych pozostałości po przeszłej działalności człowieka, głównie o zachowanej formie krajobrazowej, w tym: grodzisk, cmentarzysk kurhanowych, grobowców megalitycznych, sieci historycznych dróg i pól, umocnień, systemów uprawy, pozostałości po działalności górniczej i wydobywczej oraz wielu innych aspektów przeszłego osadnictwa, niemalże ze wszystkich epok. Największy potencjał prospekcyjny metody związany jest $\mathrm{z}$ obszarami, na których procesy niwelacyjne były najsłabsze. Długoletni brak prowadzonej orki, a zwłaszcza mechanicznej (stanowiącej zagrożenie dla zasobów dziedzictwa na największą skalę przestrzenną), m.in. na obszarach dzisiaj zalesionych (stanowiących w przypadku Polski niemalże 30\% powierzchni kraju), pozwolił obiektom archeologicznym zachować własną formę ${ }^{3}$. W konsekwencji, paradoksalnie na rozległych terenach, które z punktu widzenia tradycyjnej, powierzchniowej prospekcji stanowiły dotychczas największy problem (ze względu na ograniczenia możliwości penetracji i obserwacji), zastosowanie ALS-u przynosi najbardziej owocne rezultaty. Ponadto w specyficznych warunkach

\footnotetext{
${ }^{2}$ Używane często wymiennie w literaturze akronimy LiDAR i ALS nie są równoznaczne. Pierwszy odnosi się do pomiaru za pomocą impulsów lasera o określonej długości fali, drugi zaś jest związany z metodą pobierania danych przestrzennych, wykorzystującą skanery zamontowane na maszynach latających (samolotach, helikopterach, żyrokopterach bądź dronach). Jednakże urządzenia lidarowe są wykorzystane również w metodach naziemnego (TLS - ang. Terrestrial Laser Scanning), mobilnego (MLS - ang. Mobile Laser Scanning) i satelitarnego (SLS - ang. Satellite Laser Scanning) skaningu laserowego. Tym samym dane lidarowe uzyskuje się za pomocą specyficznie działających skanerów, ale na podstawie różnych metod poboru. Niniejszy tekst dotyczy danych lidarowych uzyskanych wyłącznie metodą ALS.

${ }^{3} \mathrm{~W}$ pewnym sensie „leśna” lokalizacja stanowisk uratowała je, wpływając na stan zachowania. Jednocześnie zjawisko to przyczyniło się do powstania błędnego przekonania, iż ta metoda może być efektywnie wykorzystana jedynie na obszarach leśnych. Choć właśnie na prospekcji nasypów oraz wkopów koncentruje się przytłaczająca większość archeologicznych aplikacji skaningu, również inne zasoby dziedzictwa kulturowego, nieposiadające własnej formy krajobrazowej, mogą być rozpoznane na podstawie analiz produktów ALS-u. Jednakże wymagane jest w tym wypadku zaistnienie rozmaitych czynników. Warunki te są omówione w dalszej części tekstu.
} 
również pewne elementy paleośrodowiska (np. paleomeandry) mogą być rozpoznane, prowadząc do umieszczenia obiektów archeologicznych w kontekście środowiskowym. Aplikacja danych lidarowych w studiach nad przeszłością otwiera więc nowe obszary badań, umożliwiając przy tym pełniejsze spojrzenie na przeszłe krajobrazy.

Na poziomie drugim, dzięki analizie produktów lotniczego skaningu laserowego może dojść do weryfikacji wyników dotychczasowych badań na znanych stanowiskach archeologicznych ${ }^{4}$. Jakość i rozdzielczość przestrzenna danych lidarowych pozwala uchwycić subtelne różnice w ukształtowaniu rzeźby terenu, w tym te wynikłe z procesu antropopresji. W konsekwencji dotychczasowe opracowania, dotyczące zarówno stanowisk, jak i całych krajobrazów, mogą zostać uszczegółowione. Tym samym ALS znajduje zastosowanie zarówno na obszarach dobrze przebadanych, przynosząc jakościowo i ilościowo nowe dane o obecnych tam zasobach dziedzictwa, obfitując w zaskakujące odkrycia, jak i w regionach pomijanych w dotychczasowej praktyce badawczej.

Jednocześnie ALS jest metodą niezwykle przydatną do celów konserwatorskich. $\mathrm{Z}$ jednej strony wyniki interpretacji produktów pochodnych skaningu są przyczyną objęcia ochroną nowo odkrytych obiektów archeologicznych. Służby konserwatorskie otrzymują wówczas m.in. dokładne informacje odnośnie do lokalizacji zasobów dziedzictwa. $Z$ drugiej strony prowadzenie sukcesywnych pomiarów pozwala na monitoring obiektów, stanowisk i krajobrazów w czasie. Tym samym możliwe jest rozpoznanie dynamiki zagrożeń często tak subtelnych, że niedostrzegalnych gołym okiem, jak i modelowanie prognostyczne np. procesów denudacyjnych.

Wraz ze zwiększającym się zainteresowaniem metodą oraz rosnącą liczbą jej zastosowań w polskiej archeologii warto zwrócić uwagę na efektywność wykorzystania generowanych produktów. Ze względu na ograniczenia skaningu, charakter obiektów archeologicznych oraz właściwości danych lidarowych należy przyjrzeć się procedurze ich poboru, przetwarzania, analiz i interpretacji. Na każdym z tych etapów dochodzi bowiem do redukcji informacji o obrazowanym wycinku terenu. Istnieje zatem zagrożenie, że bezrefleksyjne i bezkrytyczne traktowanie produktów ALS-u może mieć niekorzystny wpływ na zasoby dziedzictwa oraz konstruowaną wiedzę o przeszłości. Należy podkreślić, iż niemożliwość identyfikacji obiektów archeologicznych na opracowanych, pochodnych zobrazowaniach skaningu nie musi mieć związku z nieobecnością śladów po przeszłej działalności człowieka w danym miejscu (tudzież z brakiem własnej formy krajobrazowej). Może ona wynikać z ograniczeń metody i subiektywności danych przestrzennych oraz narzędzi analitycznych, a także niewiedzy o tych aspektach.

Celem niniejszego artykułu jest wprowadzenie do wykorzystania ALS-u w arheologii poprzez rozpoznanie potencjału skaningu i podkreślenie poziomu subiek-

\footnotetext{
${ }^{4}$ Np. Orlicka-Jasnoch 2012.
} 
tywności generowanych informacji. Ukazane będą możliwości analityczne i interpretacyjne, a także sposoby na poprawę efektywności badań. Zidentyfikowane zostaną procesy redukcji informacji o przeszłej rzeczywistości, charakterystyczne dla aplikacji danych lidarowych oraz będą zaproponowane rozwiązania mające na celu ograniczenie tych procesów. Ze względu na wzrost zainteresowania zastosowaniami omawianej metody w archeologii polskiej warto ukazać zarówno pozytywne, jak i negatywne strony wykorzystania danych lidarowych. Poprzez krytyczną analizę procedury powstawania, przetwarzania i interpretacji produktów skaningu autor niniejszego artykułu dąży do zbudowania świadomości na temat konieczności eksploracji pełnych możliwości ALS-u. Będzie to możliwe jedynie po odrzuceniu tradycyjnego pojmowania opracowań przestrzennych, z jednoczesnym uwzględnieniem subiektywności danych oraz skupieniem się na procedurze powstawania owych swoistych źródeł pośrednich ${ }^{5}$. W przeciwnym razie zarówno archeologom, służbom konserwatorskim, jak i wszystkim innym - pierwotnym oraz wtórnym odbiorcom wyników prospekcji lidarowej ostanie się silnie ograniczony i zredukowany zasób dziedzictwa archeologicznego.

\section{LOTNICZY SKANING LASEROWY A ARCHEOLOGIA}

ALS jest aktywną metodą teledetekcji, wykorzystującą do obrazowania promieniowanie elektromagnetyczne, najczęściej z zakresu bliskiej podczerwieni. Budowa i działanie zestawu urządzeń pobierających dane przestrzenne podczas skaningu laserowego zostały obszernie omówione w wielu specjalistycznych publikacjach ${ }^{6}$. Metoda ta jest powszechnie wykorzystywana do rozmaitych celów, np.: w leśnictwie, architekturze i budownictwie, hydrologii czy energetyce.

Wywodzący się m.in. z prowadzonych od lat 60. ubiegłego stulecia wojskowych testów, mających na celu wykrywanie łodzi podwodnych (ang. Airborne Laser Bathymetry - ALB), lotniczy skaning laserowy, po wielu próbach oraz dzięki rozwojowi systemów nawigacji satelitarnej, a zwłaszcza systemu GPS (ang. Global Positioning System) oraz jednostki IMU (ang. Inertial Measurment Unit), został zastosowany do celów topograficznych w Wielkiej Brytanii w połowie lat 90 . XX w. . Otrzymana wówczas gęstość chmury punktów na poziomie $1 \mathrm{pkt} / 2 \mathrm{~m}^{2}$ była zbyt mała, aby brytyjscy archeolodzy wzięli chociażby pod uwagę możliwość wykorzystania danych lidarowych $w$ badaniach przeszłych krajobrazów ${ }^{8}$. Jednak już w 2000 r. podczas międzynarodowych warsztatów NATO, odbywających się

\footnotetext{
${ }^{5}$ W ujęciu J. Topolskiego 1996.

${ }^{6}$ Np. Ackermann 1999; Hug, Ullrich, Grimm 2004; Wehr, Lohr 1999.

${ }^{7}$ Crutchley, Crow 2009, 3.

${ }^{8}$ Crutchley, Crow 2009, 3.
} 
w Lesznie, N. Holden przedstawił prawdopodobnie pierwszy referat o możliwościach wykorzystania ALS-u w studiach nad przeszłością ${ }^{9}$. Po ówczesnej prezentacji lotniczy skaning laserowy opuścił polską archeologię na 8 lat - aż do badań w okolicach Piły w 2008 r. W tym czasie, rozwijana w niesłychanym tempie metoda została zastosowana w licznych projektach w wielu krajach Europy i świata ${ }^{10}$. Konsekwencją olbrzymiego sukcesu oraz powszechności zastosowania ALS-u stały się duże programy konserwatorskie, mające na celu identyfikację zasobów dziedzictwa na podstawie danych lidarowych, obejmujące swym zasięgiem nawet całe kraje ${ }^{11}$, przynoszące olbrzymią liczbę nowych, rozpoznanych obiektów.

Nieprzypadkowo pierwsza prezentacja możliwości zastosowania ALS-u w archeologii miała miejsce w trakcie warsztatów z zakresu archeologii lotniczej. Było to spowodowane nie tylko pokrewieństwem obu metod: wspólnym spojrzeniem z lotu ptaka na krajobraz, zbliżonymi procesami przetwarzania danych czy podobnymi rezultatami końcowymi opracowań. Do tego szczególnego zainteresowania prospekcją lidarową doszło także wskutek prowadzonych przez archeologów lotniczych studiów nad nowymi rozwiązaniami technicznymi oraz możliwościami aplikacji metod zdalnej detekcji, np. nad wykorzystaniem zobrazowań satelitarnych ${ }^{12}$. Ponadto te poszukiwania były prowadzone łącznie z krytyką technologicznych aspektów wykonywania zdjęć lotniczych oraz towarzyszyła im refleksja nad naturą, charakterem i właściwościami fotografowanych obiektów ${ }^{13}$. Zastanawiano się również nad fenomenem ujawniania się różnego typu wyróżników. Z tych powodów archeolodzy lotniczy, owi pierwsi odbiorcy referatu N. Holdena, stali się nie tylko pionierami wykorzystania skaningu, lecz także, po otrzymaniu dostępu do nowego narzędzia, równolegle z jego rozpowszechnieniem podjęli istotne i pogłębione studia nad potencjałem oraz ograniczeniami wykorzystania ALS-u ${ }^{14}$. Rezultaty tych badań w znaczący sposób zmieniają często bezkrytyczne myślenie o lotniczym skaningu laserowym, eksplorując przy tym jego możliwości ${ }^{15}$.

$\mathrm{Na}$ tle dokonań europejskich dotychczasowe zastosowanie ALS-u w studiach nad przeszłymi krajobrazami ziem polskich wypada ubogo. Rezultaty pierwszego projektu, wspomnianych badań w okolicach Piły, nie zostały do tej pory opublikowane, gdyż stopień skomplikowania danych uzyskanych podczas pomiarów w chwili wygenerowania produktów skaningu znajdował się poza możliwościami anali-

\footnotetext{
${ }^{9}$ Referat N. Holdena The use of LIDAR for archaeology, wygłoszony podczas NATO Advanced Research Workshop „Aerial Archaeology - Developing Future Practice”, (Leszno 15-17.11.2000) został opublikowany później jako: Holden, Horne, Bewley 2002.

${ }^{10}$ Np. Challis 2006; Devereux, Amable, Crow, Cliff 2005; Shell, Roughley 2004; Sittler 2004.

${ }^{11} \mathrm{~Np}$. Bofinger, Hesse 2011.

${ }^{12}$ Np. Bale, Durland, Ebert et al. 1975; Powlesland 1999; Miałdun 2005.

${ }^{13}$ Np. Wilson 1975; Crawshaw 1995; Rączkowski 2002a.

${ }^{14} \mathrm{~Np}$. Doneus, Briese 2011.

${ }^{15}$ Np. Shaw, Corns 2011.
} 
tycznymi i interpretacyjnymi badaczy ${ }^{16}$. Wraz z pojawieniem się w Polsce w $2009 \mathrm{r}$. pierwszego skanera lotniczego ${ }^{17}$ oraz narastającym doświadczeniem w obróbce danych lidarowych, zdobywanym przez firmy geodezyjne podczas realizacji poszczególnych prac, wykorzystanie ALS-u w archeologii polskiej zaczęło przynosić pierwsze rezultaty. Już rok później o możliwościach aplikacji lidarów w studiach nad przeszłością w Polsce pisali Ł. Sławik i R. Zapłata ${ }^{18}$. Rozwój technologii, wraz $\mathrm{z}$ uproszczeniem procedur zastosowania metody, umożliwił jej rozpowszechnienie. $\mathrm{W}$ polskiej archeologii skaning został dotychczas wykorzystany w badaniach m.in.: obszarów zalesionych wokół Kętrzyna ${ }^{19}$, Lasu Muszkowickiego ${ }^{20}$, okolic Krzemionek Opatowskich ${ }^{21}$, Suwalszczyzny ${ }^{22}$, wybranych regionów Ziemi Lubuskiej ${ }^{23}$, rejonu Smoszewa ${ }^{24}$, terenów wokół Sławna i Polanowa ${ }^{25}$. W momencie przygotowywania niniejszego artykułu do druku gotowych publikacji jest niewiele ${ }^{26}$. Informacje o pozostałych pochodzą bezpośrednio od prowadzących wymienione projekty badawcze; zostały przekazane podczas różnorodnych konferencji naukowych lub umieszczone w serwisach PAP-u ${ }^{27}$.

\footnotetext{
${ }^{16}$ Jacek Nowakowski - informacja ustna.

${ }^{17}$ Kundzierewicz 2010.

${ }^{18}$ Sławik, Zapłata 2010.

${ }^{19}$ Badania M. Wyczółkowskiego i Muzeum im. Wojciecha Kętrzyńskiego w Kętrzynie.

${ }^{20}$ Referat A. Przybył i M. Furmanka Zapomniane cmentarzyska. Badania nieinwazyjne a ochrona
} dziedzictwa archeologicznego terenów zalesionych na przykładzie Lasu Muszkowickiego podczas konferencji „Metody geofizyczne w archeologii polskiej. Spotkanie I” (Poznań, 22-23.11.2012).

${ }^{21}$ Badania W. Migala (Państwowe Muzeum Archeologiczne), R. Zapłaty i J. Budziszewskiego (Uniwersytet Kardynała Stefana Wyszyńskiego).

${ }^{22}$ Referat C. Sobczaka An Experimental Application of Airborne Laser Scanning for Landscape Archaeology in Northeastern Poland podczas konferencji „AARG. Aerial Archaeology, Remote Sensing and the Archaeological Process" (Budapeszt, 13-15.09.2012).

${ }^{23}$ Referat Z. Kobylińskiego, M. Borowskiego, J. Budziszewskiego, T. Herbicha, A. Jaszewskiej, Ł. Kobylińskiego, Ł. Sławika, D. Wacha, J. Wysockiego Kompleksowe niedestrukcyjne rozpoznanie zasobów dziedzictwa archeologicznego Starego Kraju w woj. Lubuskim podczas konferencji „Metody geofizyczne w archeologii polskiej. Spotkanie II” (Poznań, 22-23.11.2012).

${ }^{24}$ Poster J. Czebreszuka, M. Jaegera, Ł. Pospiesznego, J. Kneisel, M. Cwalińskiego, J. Niebieszczańskiego, M. Stróżyka Badania nieinwazyjne kurhanów z epoki brązu podczas konferencji „Metody geofizyczne w archeologii polskiej. Spotkanie II" (Poznań, 22-23.11.2012).

${ }^{25}$ Badania IP UAM, finansowane ze środków Ministerstwa Nauki i Szkolnictwa Wyższego, Fundacji im. Anny Pasek oraz projektu ArchaeoLandscapes Europe (ArcLand).

${ }^{26}$ Jak dotąd opublikowane zostały artykuły Z. Kobylińskiego et al. (2012), J. Orlickiej-Jasnoch (2012) oraz J. Budziszewskiego i J. Wysockiego (2012), M. Engela et al. (2013), M. Wyczółkowskiego et al. (2013).

${ }^{27} \mathrm{~Np}$. http://www.naukawpolsce.pap.pl/aktualnosci/news,387233, archeolodzy-dokumentuja-starozyt ne-kopalnie-krzemienia.html [dostęp: 01.08.2013]; http://www.naukawpolsce.pap.pl/aktualnosci/news, 393553,archeolodzy-zastosowali-lidar-w-polnocno-wschodniej-polsce.html [dostęp: 01.08.2013]; http://www. naukawpolsce.pap.pl/aktualnosci/news,393586,pradziejowe-cmentarzyska-odkryto-na-przedgorzu-sudec kim.html [dostęp: 01.08.2013]. 


\section{PROCEDURA ZASTOSOWANIA ALS-U W BADANIACH ARCHEOLOGICZNYCH. REDUKCJA INFORMACJI}

P. Urbańczyk ${ }^{28}$ za pomocą koncentrycznie malejących kręgów zobrazował wieloetapową redukcję informacji, jaka zachodzi podczas przejścia od 1 - „kompletnego żywego przeszłego systemu społeczno-kulturowego”, przez 2 - „,skutki działania procesów formowania świadectwa stratyfikacyjnego”, 3 - efekty „działania procesów podepozycyjnych: przyrodniczych i kulturowych, które często wzajemnie się warunkują", 4 - ,niedoskonałości metod i narzędzi, jakimi operuje badacz świadectwa stratyfikacyjnego”, 5 - ,rezultaty utrwalania wybranych aspektów obserwowanego świadectwa w formie przekazów intersubiektywnie komunikowalnych i wybranych fragmentów (głównie wytworów i części konstrukcji)”, aż do 6 - powstania ,zasobu informacji ostatecznie wykorzystanych do rekonstrukcji wybranego fragmentu przeszłości czy też uchwycenia regularności charakteryzujących ją przemian"29.

Ukazany przez P. Urbańczyka proces przekształcenia, zachodzący między przeszłą rzeczywistością a możliwościami jej współczesnej interpretacji, obfituje w etapy, podczas których informacje o dziejach minionych są tracone i modyfikowane. Mimo to przeszłość jest „dostępna” dla archeologa poprzez jej pozostałe „cząstki”. Tym samym opisywany model jest podatny na krytykę ze strony archeologów o postmodernistycznych poglądach (por. Johnson 1999). Choć koncepcja koła czy też spirali hermeneutycznej jest bliższa autorowi niniejszego artykułu w określeniu relacji, jaka zachodzi między współczesnym badaczem a „tworzoną” przez niego przeszłością (por. Gadamer 1993), to uważa on, że pomysłów P. Urbańczyka nie należy odrzucać w całości. W przypadku wykorzystania lotniczego skaningu laserowego i jego produktów pochodnych w celu konstruowania wiedzy o obiektach archeologicznych (a nie o przeszłości) należy omawianą rycinę uszczegółowić i zmodyfikować (ryc. 1). Niewątpliwie utrata informacji między etapami: pierwszym (ryc. 1: 1), drugim (ryc. 1: 2) i trzecim pozostaje niezmieniona (ryc. 1: 3) bez względu na dobór przyjętej metody badań. Jednakże procedura pobierania i przetwarzania danych lidarowych wymaga rozbudowy i uszczegółowienia etapu czwartego. $\mathrm{W}$ jego obrębie pierwsza redukcja jest związana $\mathrm{z}$ wyborem ALS-u jako metody pomiaru (ryc. 1: 4A), druga zaś: ze zdefiniowaniem zakresu badań (ryc. 1: 4B). Do kolejnej dochodzi podczas poboru danych przestrzennych. Wynika ona z fizycznych możliwości użytego sprzętu, metodyki pomiaru oraz czynników, które trudno kontrolować, np. warunków atmosferycznych i współczesnych sposobów zagospodarowania terenu (ryc. 1: 4C). Następna utrata informacji wiąże się z powstaniem chmury punktów, podstawowego produktu ALS-u, i jej klasyfikacją (ryc. 1: 4D). Późniejsze redukcje są konsekwencjami procesów związanych kolejno z generowa-

\footnotetext{
${ }^{28}$ Urbańczyk 1981, 45, ryc. 15.

${ }^{29}$ Urbańczyk 1981, 45, 46.
} 
niem produktów pochodnych skaningu - Numerycznych Modeli Pokrycia Terenu (NMPT) i Numerycznych Modeli Terenu (NMT) (ryc. 1: 4E), ich analizami, a tym samym powstawaniem produktów wtórnych (ryc. 1: 4F) oraz interpretacją wszystkich zobrazowań wytworzonych podczas obróbki danych (ryc. 1: 4G). Ostateczna utrata informacji wiąże się z tworzeniem map, raportów i innych opracowań jako końcowych rezultatów aplikacji ALS-u w badaniach archeologicznych (ryc. 1: 6). Jednakże redukcję tę należy włączyć do zbioru finalnych strat, związanych z poziomem 6 według P. Urbańczyka.

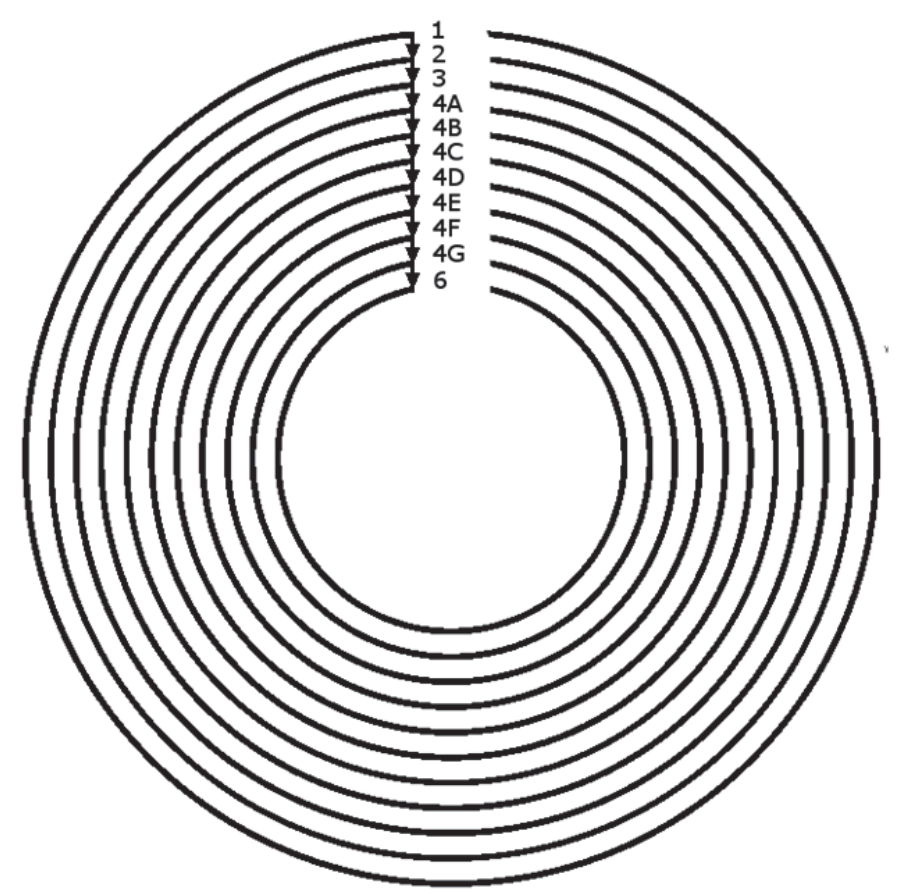

Ryc. 1. Kolejne fazy redukcji informacji archeologicznej przy wykorzystaniu ALS-u (opracowanie własne, na podstawie propozycji P. Urbańczyka 1981, 45)

Fig. 1. Subsequent stages of reduction of information characterising the application of ALS in archaeology (after P. Urbańczyk 1981, 45; modified)

Podczas korzystania $\mathrm{z}$ danych lidarowych nie można mówić o piątym poziomie redukcji, o którym pisze P. Urbańczyk, związanym z uzyskaniem ,rezultatów utrwalania wybranych aspektów obserwowanego świadectwa w formie przekazów intersubiektywnie komunikowalnych i wybranych fragmentów (głównie wytworów i części konstrukcji)"30. Owe rezultaty są bowiem ściśle związane z czwartym eta-

${ }^{30}$ Urbańczyk 1981, 46. 
pem i ujawniają się w jego poszczególnych odcinkach. Podczas wykonywania skaningu każdy fragment przestrzeni traktowany jest identycznie. Niewiele jest elementów, na które może wpłynąć subiektywnie badacz, w tym np. na określenie gęstości chmury punktów i zwiększenie jej w pobliżu znanych stanowisk archeologicznych w stosunku do pozostałych obszarów. Jednakże nawet wówczas wśród obiektów antropogenicznych znajdują się mniejsze lub większe struktury morfologiczne, niepoddane przekształceniom wynikającym z działalności człowieka (jak i struktury antropogeniczne, które nie stanowią przedmiotu badań lub zostały uznane za „naturalne"). W konsekwencji, w obrębie arbitralnie określonego zakresu opracowania (zob. redukcja informacji na poziomie 4B) wszystkie formy terenu i jego pokrycia są rejestrowane $\mathrm{w}$ ten sam sposób (różnicę może powodować jedynie odmienne, współczesne zagospodarowanie terenu - zob. redukcja informacji na poziomie 4C). Nie dochodzi zatem do „strat informacyjnych, dotyczących jedynie dokumentacji, będących wynikiem zarówno nieuniknionego subiektywizmu, którym odznacza się każdy sporządzony przez człowieka przekaz o postrzeganej przez niego rzeczywistości, jak i niemożnością jej izomorficznego utrwalenia” ${ }^{31}$. Subiektywizm i niemożność pojawiają się bowiem na etapie wyboru ALS-u jako metody prospekcji (poziom 4A), w sensie dokumentacyjnym zaś cały obszar opracowania traktowany jest identycznie.

\section{Poziom 4A. Wybór ALS-u jako metody badawczej}

Wykorzystując lotniczy skaning laserowy jako metodę prospekcji i pomiaru, archeolodzy przystają na warunki zastosowania owego sposobu pobierania danych. Godzą się oni z tym, iż możliwe do uzyskania informacje są głównie konsekwencją takich procesów formowania świadectwa stratyfikacyjnego oraz podepozycyjnych ${ }^{32}$, które umożliwiły zachowanie własnej formy krajobrazowej obiektów archeologicznych. Dotyczy to zarówno zasobów dziedzictwa znajdujących się na lądzie, jak i zlokalizowanych w strefie przybrzeżnej lub na dnie płytkich zbiorników wód słonych i słodkich. Zielony laser nowej generacji lotniczych skanerów batymetrycznych ALB pozwala bowiem na identyfikację zalanych stanowisk archeologicznych $^{33}$, jeśli wciąż mają one zachowaną formę.

Istnieje przy tym możliwość prospekcji całkowicie zniwelowanych obiektów archeologicznych dzięki zastosowaniu ALS-u. Fenomen ten wiąże się z podstawowymi aspektami wykorzystania zdjęć lotniczych w archeologii, czyli wyróżnikami roślinnymi ${ }^{34}$. W sprzyjających warunkach, wraz z pojawieniem się owych wyróżni-

\footnotetext{
${ }^{31}$ Urbańczyk 1981, 46.

${ }^{32} \mathrm{~Np}$. Schiffer 1987.

${ }^{33} \mathrm{~Np}$. Doneus, Doneus, Briese et al. 2013.

${ }^{34}$ Np. Crawford 1929.
} 
ków ${ }^{35}$, możliwe jest zadokumentowanie np. różnicy w wysokości zbóż porastających wybrane stanowisko, wynikającej z obecności pod warstwą próchnicy obiektów archeologicznych, a przez to zmiany warunków wilgotnościowych w konkretnym miejscu. Tym samym $w$ danych lidarowych to nie formy obiektów archeologicznych są zarejestrowane, lecz świadczące o nich pośrednio deniwelacje roślinności.

W konsekwencji potencjał zapisu informacji archeologicznej podczas skaningu jest olbrzymi i wiele rozmaitych obiektów może zostać zarejestrowanych w zasobie danych (zarówno te położone na lądzie, jak i pod wodą, zupełnie zniwelowane oraz o zachowanej formie krajobrazowej). Jednakże możliwości te ograniczone są nie tylko procesami formowania świadectwa stratyfikacyjnego i podepozycyjnymi, lecz także stanowią wypadkową zróżnicowanych aspektów współczesnego świata (np. aktualnego zagospodarowania terenu, mającego istotny wpływ na ujawnianie się wyróżników roślinnych). Warto podkreślić z całą stanowczością, iż rejestrowane są wyłącznie te cechy obiektów, które mogą zostać zadokumentowane pod postacią danych przestrzennych. Ten aspekt aplikacji ALS-u w studiach nad przeszłością odnosi się bezpośrednio do wspomnianej niemożności izomorficznego utrwalenia rzeczywistości, o której pisał P. Urbańczyk. Subiektywność dokumentacji, jaką charakteryzuje omówiony przez niego piąty poziom redukcji, w przypadku wykorzystania danych lidarowych związana jest nie $\mathrm{z}$ arbitralnym wyborem konkretnej części zdefiniowanego obszaru badań w celu jego utrwalenia (gdyż, jak wspomniano, cały - antropogeniczny i niewykazujący cech przekształcenia - obszar badań jest poddawany tej samej procedurze), lecz z przyjętą formą zapisu (pod postacią danych przestrzennych).

\section{Poziom 4B. Zdefiniowanie zakresu badań}

Bez wątpienia cele i zainteresowania badawcze stanowią najistotniejsze elementy określające zakres aplikacji ALS-u w studiach nad przeszłością. Uznanie, że informacje archeologiczne zapisane jako dane przestrzenne stanowić będą potrzebną warstwę zasobu, na podstawie którego wykreowana zostanie wiedza o przeszłej rzeczywistości, powoduje jednak konieczność podjęcia istotnych decyzji. Mają one zasadnicze znaczenie dla definicji zakresu pomiarów ALS. Warto podkreślić, że w tym wypadku aspekty chronologiczne nie mają znaczenia. Dla wysyłanych impulsów promieniowania elektromagnetycznego nieistotna jest bowiem proweniencja obiektu, od którego zostają odbite. W identyczny sposób, w postaci danych przestrzennych, zapisane mogą zostać obiekty powstałe w każdym okresie dziejów. Ważna natomiast jest decyzja dotycząca rodzaju zasobu danych, które mają być

\footnotetext{
${ }^{35}$ Np. Rączkowski 2002b, 52-55.
} 
wykorzystane na potrzeby studiów archeologicznych, a także granice ich zasięgu przestrzennego.

Ze względu na kryterium intencjonalności produkty lidarowe, nad którymi mogą pracować badacze przeszłości, należy podzielić na dwie kategorie. $\mathrm{Z}$ jednej strony będzie to zasób danych pobranych dla celów archeologicznych podczas zamówionego przelotu. Wykonanie skaningu na własne potrzeby pozwala na sprawowanie kontroli nad głównymi parametrami pomiarów (szerzej omówionych na kolejnym odcinku etapu czwartego redukcji). Jednakże w tym wypadku prowadzący studia nad przeszłością muszą zgodzić się na wysokie koszty uzyskania danych. Mimo że jest to rozwiązanie pozwalające w pełni wykorzystać potencjał prospekcyjny metody, pozostaje ono silnie ograniczone możliwościami finansowymi instytucji badawczych.

Choć we współczesnej dyskusji nad aplikacją lidaru w studiach nad przeszłością postuluje się, aby badacze finansowali własne przeloty $\mathrm{ALS}^{36}$, istnieje również możliwość wykorzystania zasobów drugiego rodzaju, mianowicie: danych pobranych dla innych celów, np. hydrologicznych. Nieprzeznaczone pierwotnie dla archeologii, wciąż pozostają one możliwe do wykorzystania, i niektóre $\mathrm{z}$ dużych programów konserwatorskich nastawionych na identyfikację nowych elementów dziedzictwa opierają się na produktach tego rodzaju ${ }^{37}$. Zbliża to wykorzystanie skaningu do dotychczasowej praktyki archeologii lotniczej ${ }^{38}$ oraz wiąże się z rozmaitymi aspektami utraty informacji, omówionymi w kolejnych częściach niniejszego artykułu. Nie oznacza to jednak, że te procesy redukcji charakterystyczne są jedynie dla danych pobranych dla niearcheologicznych celów. Dotyczą one również skaningu wykonywanego intencjonalnie na potrzeby studiów nad przeszłością. Jednakże w przypadku danych już raz pobranych nie ma możliwości skorygowania parametrów pomiaru.

\footnotetext{
${ }^{36}$ M. Doneus - informacja ustna.

${ }^{37} \mathrm{~Np}$. Bofinger, Hesse 2011.

${ }^{38}$ Odnosi się to do rozbieżności w wykorzystaniu ukośnych i pionowych zdjęć lotniczych przez archeologów. Te pierwsze wykonywane są najczęściej przez badaczy przeszłości wyposażonych w wiedzę na temat natury wyróżników, obiektów fotografowanych oraz warunków najbardziej sprzyjających prospekcji. W konsekwencji efektywność takiego rozwiązania jest wysoka, gdyż zastosowane są rozmaite procedury wypracowane na podstawie długoletnich doświadczeń. Te drugie, uzyskane zazwyczaj podczas realizacji rozmaitych, niearcheologicznych zadań badawczych (np. kartograficznych), nie przynoszą często żadnej informacji archeologicznej. Wynika to między innymi z faktu wykonywania zdjęć w czasie, gdy zasoby dziedzictwa przeszłości ukryte pod powierzchnią ziemi nie mogą zostać rozpoznane wskutek nieujawniania się jakichkolwiek wyróżników. Choć oba rodzaje zdjęć mają zbliżony potencjał, to ze względu na kontekst ich wykonywania istnieją olbrzymie rozbieżności między studiami opartymi na fotografiach pionowych i ukośnych. Interpretacja tych pierwszych z reguły nie prowadzi do przyrostu informacji o dziedzictwie (a przez to powoduje postrzeganie prospekcji lotniczej jako nieefektywnej i zbędnej w studiach nad przeszłością), te drugie zaś stanowią kluczowy sposób uzyskania danych o obiektach archeologicznych zlokalizowanych na ziemiach ornych (np. Rączkowski 2002b).
} 
W związku z tym utrata informacji na kolejnych etapach przetwarzania danych nie może zostać ani wstrzymana, ani cofnięta. Ponadto w tym wypadku to nie archeolodzy przetwarzają dane, lecz są jedynie odbiorcami produktów już obrobionych. To nie do nich należą decyzje odnośnie do parametrów przelotu, jak również te dotyczące algorytmów wykorzystanych podczas obróbki oraz formatu, w jakim otrzymują gotowe produkty.

Decydując się na specyficzny rodzaj danych, jaki zostanie wykorzystany, badacze przeszłości dokonują wyboru pomiędzy zasobem w pewnym sensie otwartym, którego poszczególne aspekty mogą być kontrolowane, a rezultatami skaningu niezwiązanego z archeologicznymi potrzebami badawczymi. W konsekwencji, w pierwszym wypadku wszystkie kolejne procedury przetwarzania danych mogą zostać przeprowadzone przez archeologów znających z reguły charakter obiektów, których poszukują w danych. Tym samym mogą oni zastosować takie rozwiązania analityczne, które miałyby na celu uwypuklenie informacji archeologicznej. Z kolei w drugim przypadku badacze nie decydują ani o sposobach obróbki, ani o jakości danych, ani o rodzaju uzyskanego produktu (równie dobrze mogą oni otrzymać sklasyfikowaną chmurę punktów, jak i gotowe, przetworze modele numeryczne - w zależności od polityki „,dzielenia się”, charakterystycznej dla programu lub projektu, z którego pochodzą wygenerowane produkty). Jednocześnie jest to wybór między rozwiązaniem silnie ograniczonym budżetowo (zorganizowanie nowego przelotu nad wybranym obszarem pozostaje wciąż niezwykle drogie) a zdecydowanie tańszym wykorzystaniem już pobranych danych. Ponadto, o ile w pierwszym wypadku to do badacza należy decyzja (na podstawie m.in. jego wiedzy i przeczuć, jak również zasobności portfela) odnośnie do parametrów skaningu, o tyle podczas korzystania z gotowych danych wybór ten może, do pewnego stopnia, nie należeć do niego (ze względu na ograniczenia przestrzenne programu, $\mathrm{z}$ którego pochodzą dane). W związku z tym na omawianym odcinku poziomu czwartego procesu redukcji dochodzi do wielu strat informacji o przeszłej rzeczywistości, wynikających ze zdecydowania się na ograniczenia, charakterystyczne dla wybranego zasobu danych lidarowych.

\section{Poziom 4C. Pobór danych przestrzennych}

Podczas lotniczego skaningu laserowego zamontowany na obiekcie latającym skaner emituje w kierunku ziemi (lub nieba - zależnie od przedmiotu badań) impulsy laserowe o określonej długości fali (w zależności od używanego urządzenia), które po odbiciu od napotkanych przeszkód wracają do urządzenia pod postacią ech. Zazwyczaj liczba emitowanych impulsów wynosi między 30000 a 100000 na sekundę ${ }^{39}$.

\footnotetext{
${ }^{39}$ Doneus, Briese, Fera, Janner 2008, 883.
} 
Istnieje wiele rodzajów skanerów, a wybór najbardziej odpowiedniego zależy od potrzeb i wiąże się z licznymi konsekwencjami ${ }^{40}$.

$\mathrm{Z}$ archeologicznego punktu widzenia najistotniejszy pozostaje podział pod względem sposobu rejestracji energii poszczególnego impulsu. Dotyczy on problemu rozchodzenia się emitowanego światła, które dociera do danej powierzchni (np. linii energetycznych, gałęzi, zwierząt i ludzi poruszających po skanowanym obszarze, krzewów czy gruntu) w postaci plamki o określonej średnicy ${ }^{41}$. Rozpraszający się sygnał napotyka na swej drodze różne przeszkody - np. gałęzie czy linie energetyczne, które nie odbijają całości, lecz jedynie pewien fragment wyemitowanej energii ${ }^{42}$. Podczas gdy ów refleks wraca do urządzenia, reszta energii penetruje dalej pokrycie terenu - aż do napotkania obiektu, który ostatecznie odbije całość. Starsze generacyjnie, konwencjonalne instrumenty umożliwiają rozpoznanie ech dyskretnych, czyli kilku odbić pochodzących z jednego impulsu laserowego. Oprócz pierwszego i ostatniego, w niektórych urządzeniach tego typu możliwa jest również rejestracja dwóch pośrednich ech ${ }^{43}$. Jednakże aby mogło do tego dojść, fizyczna odległość między obiektami w terenie, a zatem między poszczególnymi odbiciami, musi być większa od granic możliwości ich odróżnienia, zależnych od algorytmów charakterystycznych dla poszczególnych zestawów urządzeń. M. Doneus i C. Brie$\mathrm{se}^{44}$, powołując się na pracę K. Krausa ${ }^{45}$, piszą, iż w systemach komercyjnych możliwa jest identyfikacja obiektów oddalonych od siebie co najmniej około 1,5 m. Choć rozwiązanie to jest przydatne do odróżnienia np. wysokiej roślinności od powierzchni gruntu, jest ono ograniczone dla potrzeb studiów nad przeszłością ze względu na trudność w rozpoznaniu niewielkich obiektów archeologicznych pośród niskiej roślinności, a więc krzaków czy poszycia leśnego ${ }^{46}$.

Tymczasem wykorzystanie nowszych generacyjnie skanerów typu FullWaveform daje dużo większe możliwości prospekcyjne niż urządzenia umożliwiające rozpoznanie ech dyskretnych ${ }^{47}$. Dzięki tym instrumentom możliwa jest bowiem rejestracja pełnego sygnału od momentu wysłania impulsu do powrotu energii każdego odbicia. W konsekwencji z jednej wiązki można potencjalnie odczytać nieskończenie wiele punktów, a nie maksymalnie czterech, jak to było w przypadku

\footnotetext{
${ }^{40}$ Np. Jenkins 2006.

${ }^{41}$ Wielkość plamki lasera, odbijającej się od poszczególnych obiektów, zależy między innymi od kąta rozproszenia impulsu podczas opuszczenia skanera oraz od wysokości lotu.

${ }^{42}$ Sytuacja ta nie dotyczy, rzecz jasna, obszarów otwartych, niezakrytych żadnymi obiektami - np. pastwisk, dróg lub powierzchni dachowych. W tym wypadku bowiem całość energii odbija się od jednej przeszkody i wraca jako pojedyncze echo.

${ }^{43}$ Wagner, Ullrich, Ducic et al. 2006.

${ }^{44}$ Doneus, Briese 2006, 156.

${ }^{45}$ Kraus 2004.

${ }^{46}$ Doneus, Briese 2006, 156.

${ }^{47}$ Doneus, Briese, Fera, Janner 2008.
} 
skanerów konwencjonalnych ${ }^{48}$. To, który fragment echa z danego impulsu stanie się elementem składowym chmury punktów, a więc głównego produktu ALS-u, zależy nie tylko od celów badawczych, lecz także od algorytmów przetwarzania danych. Wygenerowanie danego punktu, położonego na interesującym badacza odcinku fali, odbywa się na podstawie przeliczeń szerokości echa oraz intensywności odbicia każdego załamania fali. $\mathrm{Z}$ tego powodu możliwa jest identyfikacja rozmaitych obiektów „zapisanych” w pojedynczym odbiciu impulsu, między którymi istnieją małe różnice wysokości ${ }^{49}$.

Ze względu na charakter obiektów archeologicznych wykorzystanie skanerów typu Full-Waveform wiąże się więc z dużo większym potencjałem prospekcyjnym niż urządzeń konwencjonalnych. Na ich korzyść wpływają również zaawansowane próby wizualizacji surowych danych, ukazujących poziomy odbicia impulsu od obiektów. Zamiast polegania na dotychczasowych wykresach, dzięki pracom rozwojowym m.in. M. Isenburga możliwy jest ogląd intensywności odbicia w formie bardziej przyjaznej dla potrzeb interpretacyjnych ${ }^{50}$. Może to w zdecydowany sposób wpłynąc na obróbkę danych i kształt obiektów archeologicznych zapisanych w chmurze punktów.

Wracające do skanera impulsy zawierają m.in. informacje o intensywności energii odbitej od danej przeszkody i lokalizacji obiektu. Dzięki integracji skanera z podsystemami nawigacji urządzenia latającego oraz obliczeń inercji poruszającej się platformy nośnej (wychyleń podczas lotu, rejestrowanych w urządzeniu IMU), a także rejestracji pozycji skanera z wykorzystaniem umieszczonych na maszynie latającej odbiorników systemów nawigacji satelitarnej oraz dzięki uzyskaniu poprawek GPS z naziemnych stacji referencyjnych możliwe jest określenie pionowych i poziomych współrzędnych danego echa - punktu odbicia w wybranym układzie geodezyjnym lub geograficznym ${ }^{51}$. W ten sposób z uzyskanych danych po wstępnym przetwarzaniu powstaje chmura punktów.

Utrata informacji na poziomie pozyskiwania danych przestrzennych jest związana nie tylko z wyborem typu skanera, lecz także z ustawieniami skanowania, w tym z gęstością pomiaru. Wpływ na nią mają zróżnicowane czynniki. Dominujący jest cel zastosowania ALS-u, gdyż metodyka prowadzenia pomiarów dla potrzeb archeologicznych jest, w pewnych aspektach, inna niż np. dla leśnictwa lub celów kartograficznych. W studiach nad przeszłością uwaga badaczy skupia się przede wszystkim na odbiciach od gruntu, czyli zazwyczaj echach ostatnich (choć nie

\footnotetext{
${ }^{48}$ Wagner, Ullrich, Ducic et al. 2006.

${ }^{49}$ Doneus, Briese, Fera, Janner 2008, 884, ryc. 1.

${ }^{50} \mathrm{http}: / /$ rapidlasso.com/2013/06/21/release-of-pulsewaves-full-waveform-lidar-format [dostęp: 01.08 . 2013].

${ }^{51}$ Choć podstawowym systemem odniesienia ALS-u ze względu na wykorzystanie odbiorników GPS jest WGS 84, to podczas dalszego przetwarzania danych możliwe jest przeliczenie wartości punktów do pozostałych układów współrzędnych.
} 
wszystkie echa ostatnie pochodzą z gruntu). Ponadto, ze względu na charakter obiektów archeologicznych, które mogą być zidentyfikowane na podstawie danych lidarowych, najlepiej żeby owych punktów było jak najwięcej.

Ze względu na efektywność, skaning dla potrzeb archeologicznych skupionych na identyfikacji obiektów o własnej formie krajobrazowej powinien być prowadzony przede wszystkim wczesną wiosną lub późną jesienią, gdy wegetacja jest wstrzymana, a śnieg nie przykrywa ziemi. Śnieg, podobnie jak woda, utrudnia odbicie fali podczerwonej. W konsekwencji echa nie wracają do skanera (pewnym wyjątkiem są skanery wykorzystywane w metodzie $\mathrm{ALB}^{52}$ ). Tymczasem wykonanie skaningu dla celów kartograficznych, pomimo skupienia się na ostatnich echach, charakteryzuje się jednocześnie dużą generalizacją. Subtelne formy terenowe (np. niewielkie kurhany) nie mają znaczącego wpływu na dokumentację form topograficznych, więc pożądana, niezbyt duża gęstość skanowania może nie pozwolić na późniejszą identyfikację takich obiektów.

Skupienie się na obiektach archeologicznych o własnej formie krajobrazowej wywołuje jednak istotny konflikt. Jak wspomniano, na podstawie danych lidarowych i w sprzyjających okolicznościach możliwe jest także rozpoznanie obiektów zupełnie zniwelowanych. Jednak wyróżniki roślinne, na podstawie których może dojść do identyfikacji stanowisk płaskich, pojawiają się np. w polskich warunkach głównie w czerwcu i lipcu. Tymczasem najlepszymi porami roku na wykonanie na obszarach leśnych pomiarów ALS, mających na celu identyfikację obiektów o zachowanej formie, są wczesna wiosna i późna jesień. W konsekwencji, wraz z określeniem daty przelotu dochodzi do redukcji potencjału prospekcyjnego metody. Choć zdaniem M. Doneusa, z uwagi na koszty wykorzystania ALS-u pomiary należy wykonywać przede wszystkim na obszarach zalesionych, a ziemie orne zostawić tradycyjnemu rozpoznaniu lotniczemu ${ }^{53}$, to nie można zanegować faktu, iż podczas określania daty przelotu dochodzi do redukcji potencjału poznawczego metody ze względu na ograniczenia możliwości identyfikacji danej grupy obiektów.

Do utraty informacji archeologicznej dochodzi również wskutek innych parametrów pomiaru. Wynika ona zarówno z fizycznych możliwości, np. typu skanera i jego dokładności ${ }^{54}$, bądź rodzaju platformy nośnej, jak i metodyki pomiaru (oprócz wspomnianego wcześniej wyboru pory roku, także wysokości ${ }^{55}$ i prędko-

\footnotetext{
${ }^{52} \mathrm{~Np}$. Doneus, Doneus, Briese et al. 2013.

${ }^{53} \mathrm{M}$. Doneus - informacja ustna.

${ }^{54}$ Przykładowo: bezwzględna dokładność pomiaru względem układu wysokości Kronsztad skanera Riegl LMS-Q680i wynosi Z: $\mathrm{mh} \leq+/-0,15 \mathrm{~m}$, a względna punkt do punktu Z: $\mathrm{mh} \leq+/-0,01 \mathrm{~m}$ - referat M. Borowskiego i Ł. Sławika Skaning laserowy. Doświadczenia firmy MGGP Aero podczas „XX Ogólnopolskiej Konferencji Fotointerpretacji i Teledetekcji. Telegeoinformacja zintegrowanym systemem badań środowiska" (Warszawa, 21-23.09.2010).

${ }^{55}$ Wraz ze wzrostem pułapu lotu zwiększa się rozmiar plamki lasera (ang. footprint) na powierzchni (chociaż parametr ten może w przypadku niektórych urządzeń zostać skorygowany ograniczeniem
} 
ści $^{56}$ lotu, warunków atmosferycznych ${ }^{57}$, charakterystyki skanowanego terenu ${ }^{58}$, kąta prowadzonego skaningu $^{59}$, pokrycia szeregowego ${ }^{60}$ itd.). Istnieje wiele aspektów możliwej utraty informacji, a zatem wiedza na temat możliwości ALS-u, charakteru danych uzyskiwanych podczas skanowania oraz znajomość własnych potrzeb wydają się niezbędne w momencie planowania pomiarów.

Aby najpełniej wykorzystać potencjał metody, nie można polegać jedynie na doświadczeniu firm oferujących usługi skanowania, gdyż najczęściej pochodzi ono $\mathrm{z}$ innych niż archeologiczne potrzeb. Badacze muszą być świadomi subiektywności danych przestrzennych i ograniczeń w możliwościach ich pozyskania, a także złożoności wpływu metodyki na dalsze wyniki. Dlatego procedura planowania pomiarów jest niezwykle istotna. Założona gęstość 4 impulsów na $\mathrm{m}^{2}$ zaowocuje uzyskaniem danych o innej jakości niż wówczas, gdy odbić tych będzie 8 bądź nawet kilkadziesiąt (jak np. w przypadku wykorzystania śmigłowców jako platformy nośnej). Do pewnego stopnia inaczej wyglądać będzie na produktach lidarowych dany obszar, jeżeli zostanie zeskanowany wczesną wiosną, a inaczej w środku lata. Choć m.in. przez zmianę wysokości i prędkości lotu można zwiększyć gęstość oraz poprawić jakość danych, to wraz z nimi rośnie także cena usługi. $\mathrm{Z}$ tych powodów utrata informacji, do jakiej dochodzi podczas wykonywania skaningu, jest wypadkową możliwości finansowych, rodzaju zestawu urządzeń pomiarowych, metodyki, wiedzy zamawiającego na temat efektywności wykonywanych prac oraz jakości uzyskiwanych danych przestrzennych. Każdy z tych elementów ma wyraźny wpływ na wygląd generowanej chmury punktów.

kąta rozproszenia impulsu). Tym samym powiększa się obszar płaszczyzny, której wartość wysokości jest uśredniana dla danego echa.

${ }^{56}$ Wykorzystanie helikopterów, żyrokopterów czy dronów pozwala na ograniczenie prędkości przelotu, a nawet, w przypadku śmigłowców i dronów, na swoiste zawiśnięcie w powietrzu oraz zwiększenie liczby wysyłanych impulsów w danym kierunku.

${ }^{57} \mathrm{~W}$ czasie wstrzymanej wegetacji istnieje prawdopodobieństwo wystąpienia i utrzymywania się niekorzystnych warunków atmosferycznych (np. opadów deszczu, wichur), co w zdecydowany sposób ogranicza sezon pomiarowy. Ponadto maszyna znajdująca się w powietrzu narażona jest na działanie wiatrów i ruchów powietrza, wpływających na kierunek i prędkość lotu. Uwidacznia się to m.in. w rozkładzie przestrzennym ech.

${ }^{58}$ Obszary stosunkowo płaskie nie stanowią większego problemu metodycznego, jednakże skanowanie terenów o dużych przewyższeniach charakteryzuje się dużą trudnością w regularnej dystrybucji punktów pomiarowych, zwłaszcza na stokach.

${ }^{59}$ Często postuluje się, iż podczas skanowania obszarów leśnych należy tak ustawić parametry, aby urządzenie odbierało echa pochodzące $\mathrm{z}$ nadiru bądź kąta zbliżonego do niego. Jednak w niektórych przypadkach skaning wykonany przy dużym kącie emisji impulsów przynosi lepsze rezultaty (Doneus, Briese 2011, 64).

${ }^{60}$ Większe pokrycie szeregowe ułatwia łączenie szeregów podczas obróbki danych, a także umożliwia uzyskanie większej gęstości impulsów nie tylko na obszarach otwartych, lecz także na tych o utrudnionej penetracji fali (np. z powodu poszycia leśnego). 


\section{Poziom 4D. Powstanie chmury punktów i jej klasyfikacja}

W 2013 r. M. Isenburg stworzył PulseWaves, czyli nowy format wymiany informacji o impulsach emitowanych przez skanery typu Full-Waveform ${ }^{61}$. Jest on podobny do standardowego formatu wymiany danych lidarowych (.las), opracowanego przez American Society for Photogrammetry and Remote Sensing (ASPRS). Jednak zamiast zapisu informacji o punktach dyskretnych zawiera on informacje o impulsach laserowych z nadaną georeferencją, a także o zdigitalizowanych partiach wysłanej oraz odbitej energii (ryc. 2). Prace nad tym formatem zapisu danych pozwolą z czasem na przeprowadzenie efektywniejszej obróbki „surowych” danych lidarowych. Na podstawie wizualizacji informacji zapisanych w plikach PulseWaves możliwe będzie m.in. podjęcie bardziej świadomej decyzji odnośnie do wygenerowania punktu dyskretnego w najbardziej odpowiednim ,miejscu” na długości odcinka echa.

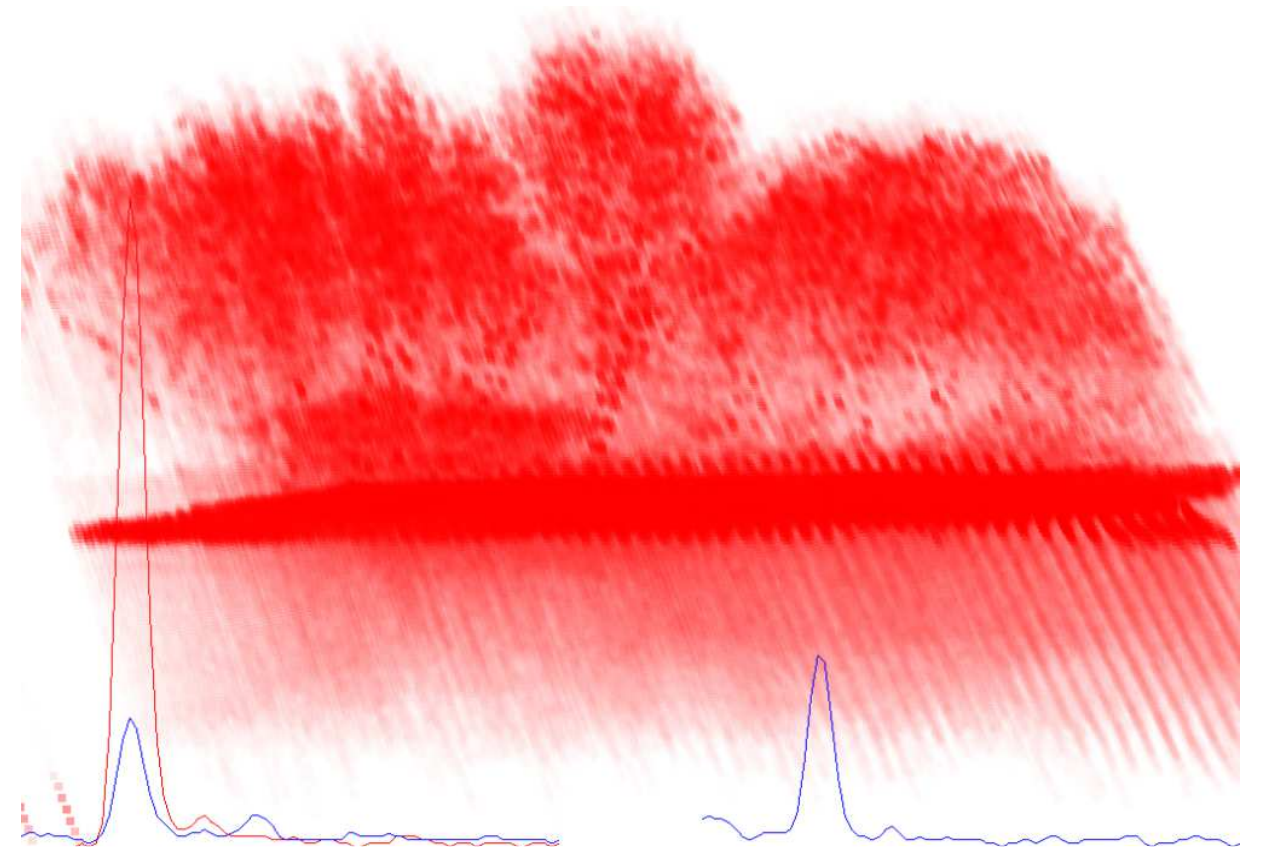

Ryc. 2. Wizualizacja informacji zapisanej w pliku w formacie PulseWaves, prezentująca zapis fali odbitej od wszystkich napotkanych obiektów wraz z jej liniowym wychyleniem. () Rapidlasso - M. Isenburg

Fig. 2. Visualisation of information saved as a file in PulseWaves format, presenting the character of waves (reflected from every encountered object) and its inclination. (C) Rapidlasso - M. Isenburg

${ }^{61}$ Jego pierwsza prezentacja miała miejsce podczas konferencji „RIEGL LiDAR 2013” (Wiedeń, 25-27.06.2013). 
Rozwój sposobu zapisu informacji takiego typu z pewnością należy obecnie do najbardziej zaawansowanych problemów badawczych, związanych z danymi uzyskanymi metodą skaningu, a PulseWaves mają potencjał, aby stać się najpowszechniejszym formatem wymiany informacji lidarowych. Jednak aby tak się stało, należy poczekać na wyniki postępujących modyfikacji programistycznych oraz prób aplikacyjnych. Tymczasem podstawowym produktem skaningu pozostają wciąż chmury punktów $\mathrm{w}$ formacie .las. Zawierają one dane w postaci punktów dyskretnych o odbiciach ze skanerów konwencjonalnych lub wyinterpretowanych za pomocą przyjętych algorytmów z wykresów wychylenia odbitej fali skanerów typu FullWaveform (ryc. 3). Powstanie chmur punktów wiąże się z różnorodnymi procesami

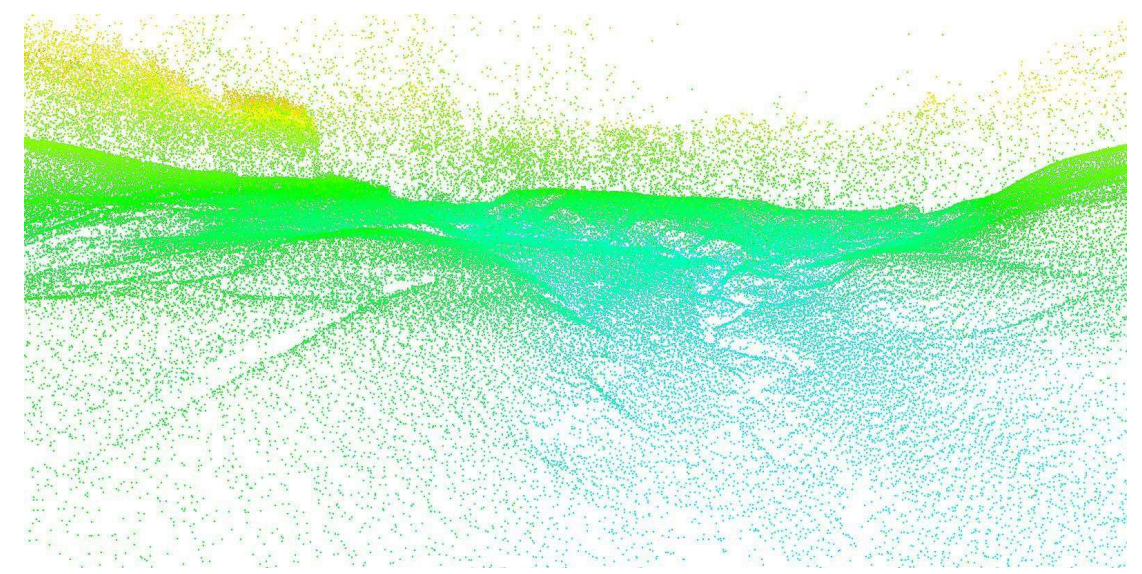

Ryc. 3. Chmura punktów. Kolorystykę definiuje wysokość punktu n.p.m. (opracowanie własne)

Fig. 3. Point cloud. Colour differentiation depending on the altitude (by Author)

wstępnej obróbki, które mają na celu m.in. umieszczenie chmury w „odpowiednim” miejscu w przestrzeni, poprzez nadanie wszystkim punktom georeferencji oraz wyrównanie szeregów skanowania (ang. strip adjustment). Chociaż powierzchownie etapy te mają niewiele wspólnego $\mathrm{z}$ archeologicznym użyciem danych przestrzennych, ich efekty mają podstawowe znaczenie nie tylko dla poprawnego, relatywnego połączenia poszczególnych danych w zbiorze, lecz także wpływają na czytelność produktów pochodnych ALS-u. Błędy lub niedoskonałości towarzyszące np. wyrównaniu szeregów skanowania mogą spowodować pojawienie się na NMT/NMPT pewnych „obiektów”, które będą mogły zostać zinterpretowane jako potencjalnie $\operatorname{archeologiczne~}^{62}$ (ryc. 4). Jednak w żaden sposób nie istnieją one poza plikami $\mathrm{z}$ zapisaną, niepoprawną zawartością.

\footnotetext{
${ }^{62}$ Np. Doneus, Briese 2011, 64, ryc. 5.5; Crutchley, Crow 2009, 27, ryc. 34.
} 


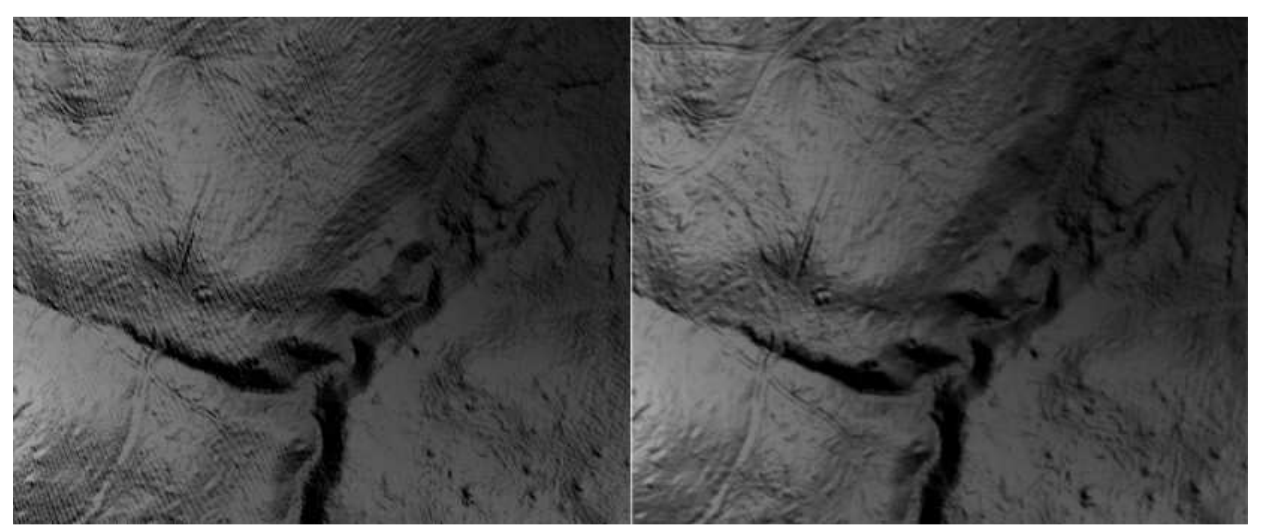

Ryc. 4. Przykład „fałszywych” obiektów archeologicznych na modelu terenu. Po lewej widoczne na analizie cieniowania NMT szeregi wąskich linii, biegnące w różnych kierunkach, przypominają ślady po prowadzonej w przeszłości orce. Nie istnieją one jednak w rzeczywistości. Powstają one jako rezultat błędnego przetwarzania danych. Po prawej prawidłowo wygenerowany model numeryczny. Okolice Polanowa (opracowanie własne)

Fig. 4. An example of false archaeological objects visible on the DTM. On the left a number of rows of thin lines running in different directions, which could resemble remains of past ploughing. However these features do not exist in reality and were created only as a result of incorrect data processing. On the right a corrected DTM is presented. A vicinity of Polanów (by Author)

Wygenerowana i wstępnie obrobiona chmura punktów jest poddawana klasyfikacji. Na tym etapie, dzięki wiedzy na temat obiektów oraz form terenowych, z zastosowaniem zróżnicowanych algorytmów (autorskich bądź właściwych specjalistycznemu oprogramowaniu komputerowemu) wszystkie elementy chmury zostają sklasyfikowane. Każdy punkt, na podstawie swoich właściwości oraz lokalizacji, zostaje przypisany do jednej z klas. Choć poszczególni analitycy danych lidarowych mogą tworzyć własne klasyfikacje, to jednym z najczęściej stosowanych standardów są definicje klas ustalone przez American Society for Photogrammetry and Remote Sensing (ASPRS 2012).

Podczas klasyfikacji nie tylko dochodzi do odrzucenia błędów w pomiarach (np. usunięcia ech odbitych od przelatujących ptaków), lecz także tworzy się podwaliny pod wygenerowanie NMT/NMPT, odróżniając odbicia z gruntu (charakteryzujące rzeźbę terenu) od pozostałych. Na tym etapie może dojść do „wymazania”, czyli niesklasyfikowania jako punktów pochodzących z powierzchni ziemi subtelnych różnic w terenie, jakimi często charakteryzują się obiekty archeologiczne (ryc. 5). Wpływ na to ma między innymi wspomniany wcześniej brak zainteresowania takimi formami krajobrazowymi, np. dla celów kartograficznych, jak i brak wiedzy na temat specyfiki obiektów archeologicznych. Paradoksalnie na wirtualne „oczyszczenie” gruntu z obiektów o własnej formie krajobrazowej najbardziej narażone są obszary zalesione (echa odbite od kurhanów wystających np. $30 \mathrm{~cm}$ ponad 
otaczający je teren mogą zostać sklasyfikowane jako odbicia od niskiej roślinności, poszycia leśnego, a przez to nieuwzględniane podczas generowania NMT). Zastosowanie skanera Full-Waveform podczas pomiarów, analizy szerokości echa i wykorzystanie rozmaitych technik służących wyinterpretowaniu odpowiedniego punktu dyskretnego $\mathrm{z}$ pełnej informacji o intensywności odbicia, np. metody eliminacji Gaussa $^{63}$, w znaczący sposób zwiększają efektywność klasyfikacji chmury punktów na potrzeby archeologiczne.

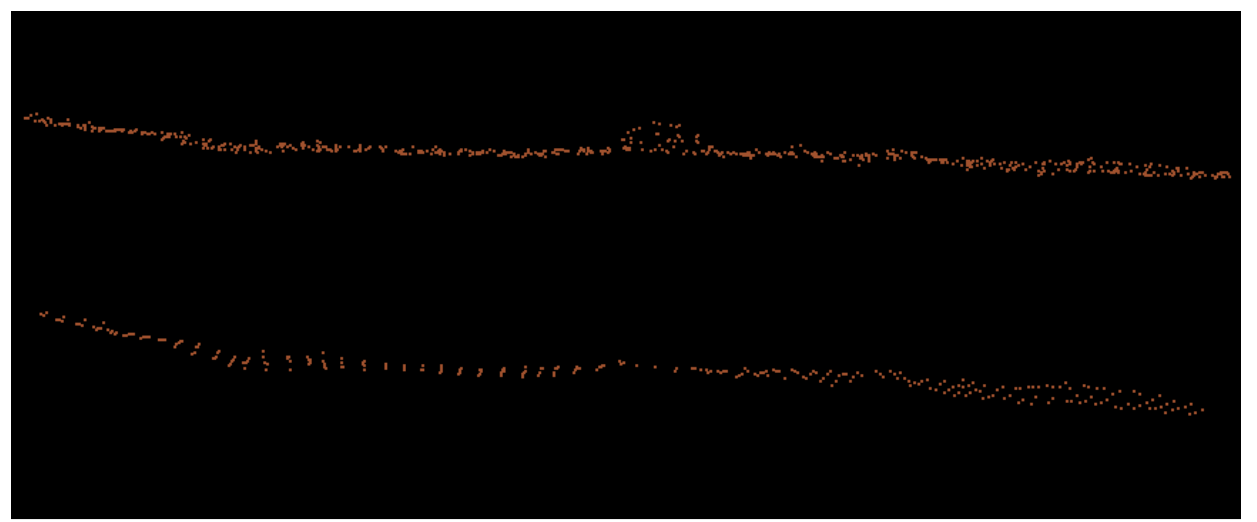

Ryc. 5. Przekroje przez punkty sklasyfikowane jako 'grunt' w tej samej chmurze punktów, poddanej dwóm różnym metodom klasyfikacji. Widoczne punkty pomiaru odbite od kurhanu (na górnym przekroju) zostały sklasyfikowane w drugim przypadku jako 'niska roślinność'. W konsekwencji, w tym drugim przypadku obiekt nie zostanie włączony w powierzchnię terenu badanego obszaru, będzie niejako usunięty z danych i wyłączony z dalszej obróbki oraz analizy (opracowanie własne)

Fig. 5. Two sections - presenting 'a ground' points only - of the same point cloud processed using two different methods of classification. Points reflected from the burial mound (upper section) were in the second case classified as the 'low vegetation'. In consequence, this object would not be included in the DTM and in a sense 'deleted' from the data. It would be excluded from further processing and analyses (by Author)

W konsekwencji, aby w pełni wykorzystać potencjał pomiarów ALS, konieczne jest poznanie natury danych oraz znajomość metod ich przetwarzania. Stworzenie oraz sklasyfikowanie chmury punktów wiąże się z licznymi procesami utraty informacji. Dzięki archeologicznemu nadzorowi nad tymi etapami możliwe jest uzyskanie znacznie więcej pozytywnych wyników interpretacji zobrazowań lidarowych $\mathrm{i}$ istotne ograniczenie redukcji. Poza tym przemyślane podejście do badań pozwala na uświadomienie sobie, że brak archeologicznych obiektów (widocznych w danych) o własnej formie krajobrazowej w wybranym miejscu nie oznacza, iż obiektów tego typu w danej przestrzeni nie ma. Ich nieujawnianie się w posiadanych pli-

\footnotetext{
${ }^{63}$ Doneus, Briese 2006, 159.
} 
kach może bowiem wynikać z przyjętej procedury badawczej, która uniemożliwiła takie rozpoznanie ${ }^{64}$.

Z tego powodu jedną z najbardziej podstawowych analiz chmury punktów powinna być analiza rzeczywistej, a nie zakładanej przed przelotem gęstości pomiaru. W odniesieniu do celów archeologicznych dotyczy to przede wszystkim plików po wykonanej klasyfikacji. Pozwala ona uzyskać niezwykle cenne informacje na temat potencjału skaningu, mówiące o rzeczywistych możliwościach interpretacyjnych. Umożliwia ona wyznaczenie obszarów, w których liczba ech odbitych od gruntu jest niewystarczająca dla identyfikacji obiektów archeologicznych (ryc. 6).

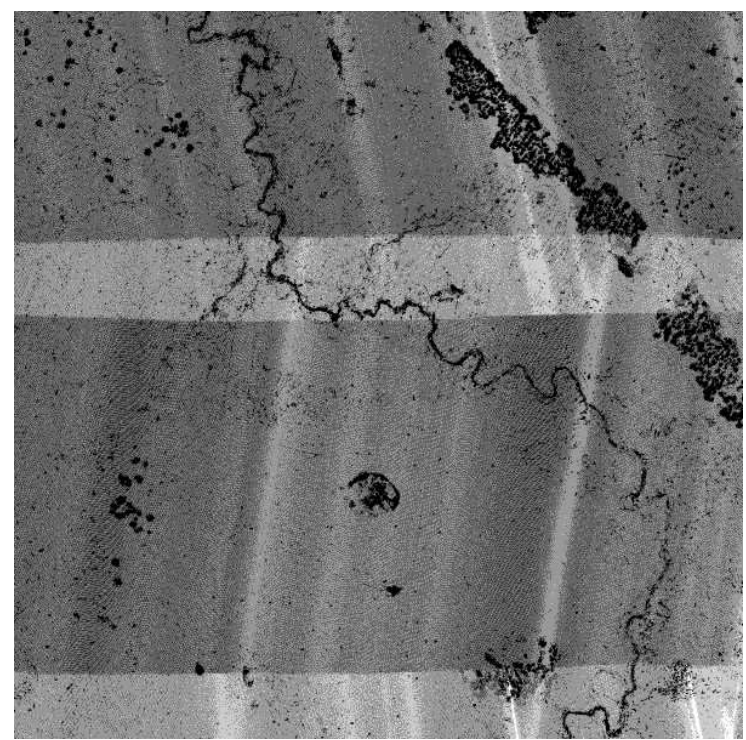

Ryc. 6 Analiza dystrybucji punktów pomiarowych sklasyfikowanych jako 'grunt' na $\mathrm{m}^{2}$. Podział kolorystyczny (od czarnego do białego) na 6 klas (0: brak punktów z gruntu; 1: 1-2 punkty; 2 - 3-5 punktów; 3: 6-10 punktów; 4: 11-20 punktów; 5 - powyżej 20 punktów $/ \mathrm{m}^{2}$ ). Uwagę zwracają swoiste naprzemienne ,pasy” jasne i ciemne. Są one wynikiem nakładania się na siebie szeregów skaningu (szerokie pasy równoleżnikowe), a także możliwości technicznych skanera oraz warunków atmosferycznych podczas pomiarów (wąskie pasy południkowe z odchyleniem na wschód lub zachód). Okolice Polanowa (opracowanie własne)

Fig. 6. Analysis of distribution of metering points, classified as 'a ground' at a square meter. Colours (from black to white) define 6 classes (0: no ground points; 1 : $1-2$ ground points; $2-3-5$ ground points; 3: 6-10 ground points; 4: 11-20 ground points; 5 - ground points $/ \mathrm{m}^{2}$ ). A number of specific alternating (bright and dark) stripes should be noticed. These resulted from overlapping of lidar stripes (wide horizontal stripes) and the technical issues characterising used scan system as well as e.g. atmospheric conditions during the data acquisition (thin, nearly vertical stripes). A vicinity of Polanów (by Author)

${ }^{64}$ To samo dotyczy procedury uzyskiwania zdjęć lotniczych. Błędne wykonanie fotografii w czasie nieujawniania się żadnego z wyróżników nie pozwoli bowiem na identyfikację obiektów archeologicznych, nawet mimo ich fizycznej obecności na danym obszarze. 


\section{Poziom 4E. Wygenerowanie modeli numerycznych}

Punty dyskretne zapisane w chmurze punktów mają zróżnicowane atrybuty, m.in. współrzędne w wybranym układzie, wartość intensywności odbicia, przynależność do szeregu nalotu czy typu przypisanego w procesie klasyfikacji. Pliki .las wymagają zarówno umiejętności przetwarzania oraz analiz, jak i wiedzy pozwalającej na ich interpretację, czyli przypisanie danego punktu do wybranej klasy. Na podstawie chmury punktów generuje się numeryczne modele terenu i pokrycia terenu, które przez swoją „,ciągłość” są bardziej przyjazne użytkownikom danych. Należy podkreślić z całą mocą, że interpretacja i klasyfikacja punktów ma fundamentalny wpływ na wygląd analizowanych później NMT i NMPT ${ }^{65}$.

W celu wygenerowania numerycznego modelu terenu należy przetwarzać jedynie punkty sklasyfikowane jako ,grunt”, podczas gdy kreacja modeli pokrycia terenu wymaga wykorzystania punktów wszystkich klas, oprócz błędnych, wynikających z rozmaitych szumów, bądź odbitych od chmur czy przelatującego ptactwa. Produkty te powstają np. w wyniku interpolacji punktów i zawierają wartość wysokości w regularnej siatce $\mathrm{z}$ oczkiem kwadratowym o arbitralnie zdefiniowanej wielkości ,x” (np. $1 \mathrm{~m})^{66}$. W związku z tym na podstawie NMT lub NMPT niemożliwe jest rozpoznanie obiektu o rozmiarze mniejszym niż „x” (nawet jeśli jest on „,zarejestrowany" w chmurze punktów). Tworzenie numerycznych modeli jest więc etapem, na którym może dojść do znacznej redukcji informacji. W wyniku przeprowadzonego skaningu i wstępnej obróbki na $1 \mathrm{~m}^{2} \mathrm{w}$ pliku las może być więcej niż jeden punkt pomiarowy. Jednak istniejące m.in. różnice wysokości nie zostaną wyodrębnione, jeżeli oczko siatki wyniesie $1 \mathrm{~m}$. Wraz ze zmniejszeniem rozdzielczości przestrzennej uzyskuje się większą przejrzystość produktu. Choć możliwe jest stworzenie modelu o drobnym oczku siatki, co umożliwiłoby ogląd niewielkich obiektów i form terenowych, a przez to uzyskanie większej szczegółowości (ryc. 7), to zwiększenie rozdzielczości przestrzennej NMT/NMPT powoduje wzrost rozmiaru plików, a tym samym rosną wymagania stawiane przed dostępnym sprzętem komputerowym oraz oprogramowaniem ${ }^{67}$. Ponadto $w$ niektórych przypadkach modele

\footnotetext{
${ }^{65}$ Interpretację produktów lidarowych w celu identyfikacji np. obiektów archeologicznych o własnej formie krajobrazowej, zlokalizowanych na obszarach zalesionych, przeprowadza się w głównej mierze na numerycznych modelach terenu. Tymczasem, mając do czynienia z produktami skaningu obszarów rolnych, należy zwrócić uwagę przede wszystkim na numeryczne modele pokrycia terenu. Dotyczy to nie tylko prospekcji obiektów zniwelowanych, a więc możliwych do rozpoznania na podstawie np. wyróżników roślinnych, lecz także tych mających własną formę krajobrazową. Na NMPT ziem ornych obiekty archeologiczne są bowiem często dużo bardziej czytelne niż na NMT tych samych obszarów.

${ }^{66}$ Inną możliwą metodą uzyskania modeli terenu/pokrycia terenu jest triangulacja rozproszonych punktów, tworząca nieregularną siatkę trójkątów TIN (ang. Triangulated Irregular Network).

${ }^{67}$ Zbędne jest dążenie uzyskania rozdzielczości NMT/NMPT większej niż gęstość punktów pomiarowych, np. generowanie modeli o oczku siatki $0,25 \mathrm{~m}$, podczas gdy w czasie skanowania uzyskana została chmura punktów o średniej gęstości $4 \mathrm{pkt} / \mathrm{m}^{2}$.
} 


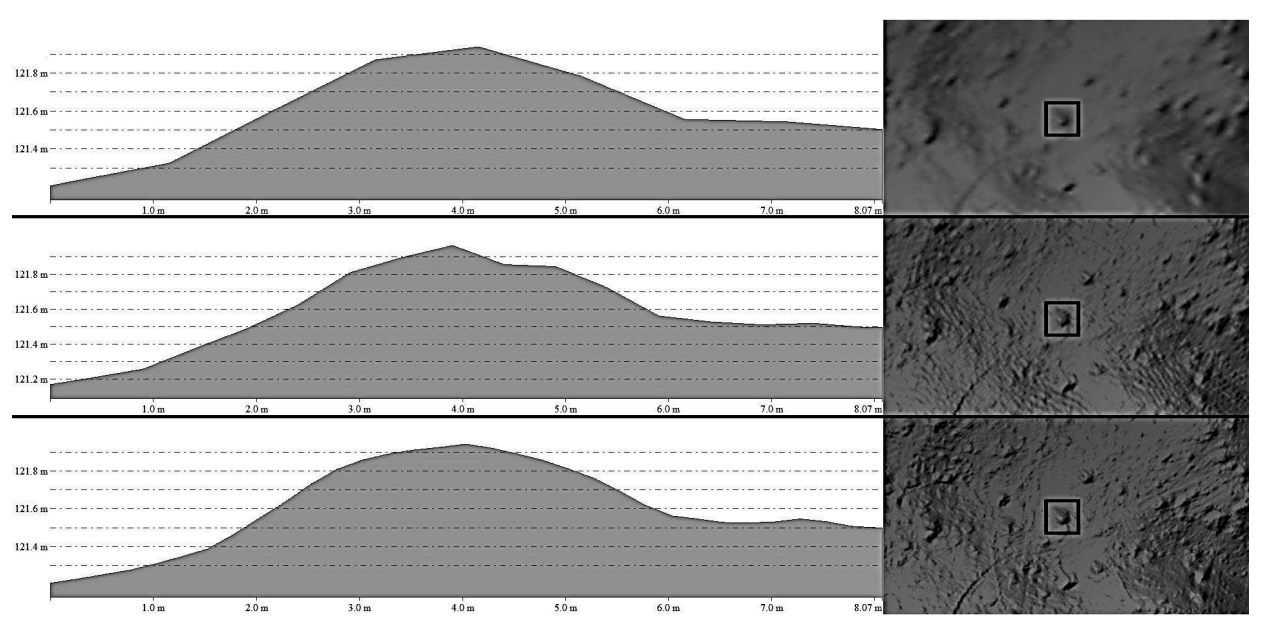

Ryc. 7. Porównanie analiz cieniowania trzech modeli terenu, o rozdzielczości przestrzennej odpowiednio: $1 \mathrm{~m}$ (górny), 0,5 m (środkowy), 0,25 m (dolny), oraz związanych z nimi trzech przekrojów przez wybrany kurhan. Zmiana jakości analizowanych modeli przyczynia się zarówno do możliwości rozpoznania potencjalnych obiektów archeologicznych na przetwarzanych NMT, jak i wpływa na wizualne rezultaty badań. Kurhan 'zapisany' na najmniej dokładnym modelu jest bardziej spłaszczony i rozciągnięty niż na pozostałych przekrojach, błędy zaś przy tworzeniu NMT o rozdzielczości $0,5 \mathrm{~m}$ wpłynęły na zaburzenie rzeźby badanego nasypu. Efektywna zmiana rozdzielczości NMT możliwa jest jedynie wtedy, gdy są dostępne pliki chmury punktów. Okolice Polanowa (opracowanie własne)

Fig. 7. A comparison of three shaded DTMs with different spatial resolution ( $1 \mathrm{~m}$ - upper; $0.5 \mathrm{~m}$ middle; 0.25 lower respectively) and corresponding three sections of a burial mound. The modification in quality of DTMs influences the possibility of archaeological prospection and has an impact on the visual results of studies. A mound seen on the least precise model is flatter and more stretched than in the other cases. Moreover, the errors characterising the creation of a $0.5 \mathrm{~m}$ DTM impacts the relief of analysed object. An effective alternation of spatial resolution is possible only when in possession of point clouds. A vicinity of Polanów (by Author)

o dużej rozdzielczości przestrzennej są mniej czytelne niż te o mniejszej, co w istotny sposób wpływa na interpretację, a błędy podczas generowania NMT/NMPT mogą prowadzić do powstawania potencjalnych obiektów archeologicznych, istniejących jedynie $w$ danych, a nie $\mathrm{w}$ rzeczywistości. Zmiana rozdzielczości ma także istotny wpływ na sposób, w jaki obiekty jawią się w na modelach. W konsekwencji wyjściowy NMT/NMPT powstaje jako kompromis zawarty między celem pomiarów, sposobem jego wykonania i przetworzenia danych, a także możliwościami analitycznymi, sprzętowymi i finansowymi. Po raz kolejny dochodzi więc do utraty informacji, której poziom zależy od wymienionych wyżej wskaźników.

Wspomniane wcześniej aspekty procedury, związane z metodyką prowadzenia pomiarów, klasyfikacją chmury punktów oraz powstawaniem NMT/NMPT, świadczące jednocześnie o wysokiej subiektywności danych lidarowych, są jedynie „,wierzchołkiem góry lodowej”, błędnego uznania tych modeli za swoisty „obiektywny" obraz rzeczywistej rzeźby terenu, za końcowy produkt analiz. Tymczasem 
ów produkt jest tylko jednym z wielu możliwych przedstawień danych przestrzennych, podlegającym regułom generalizacji i reprezentacji oraz ograniczeniom metodycznym, podobnie jak wszystkie opracowania kartograficzno-geodezyjne. Ponadto ze względu na liczne ograniczenia NMT/NMPT nie mogą stać się finalnym produktem obróbki danych lidarowych dla celów archeologicznych.

\section{Poziom 4F. Analizy modeli numerycznych i ich pochodnych}

Kolejny etap utraty informacji związany jest $\mathrm{z}$ analizami NMT/NMPT oraz ich pochodnych. Modele numeryczne niosą pewną informację archeologiczną, jednakże opieranie interpretacji na nich bez wcześniejszego przeprowadzenia specjalistycznych analiz powoduje ograniczenie potencjału prospekcyjnego ALS-u (ryc. 8). Możliwe jest zastosowanie narzędzi analitycznych, pozwalających wydobyć obiekty po-

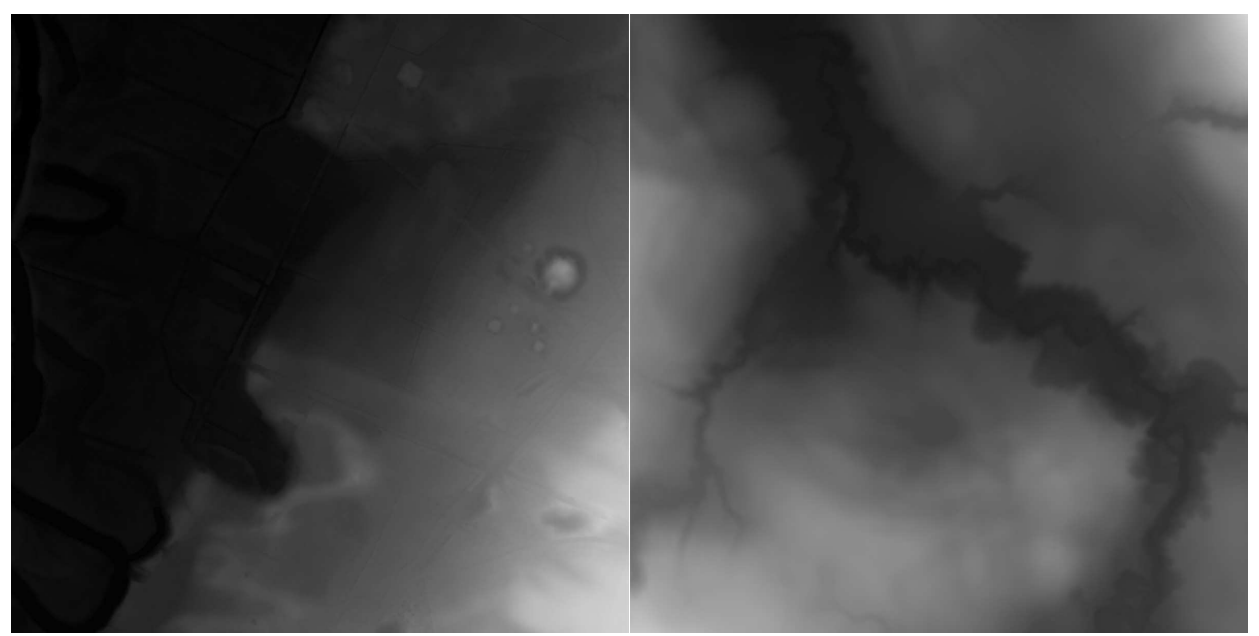

Ryc. 8. Dwa NMT w skali szarości. Z lewej: okolice Sławna, z prawej: rejon Polanowa. Choć niepoddany żadnej analizie (wykorzystującej algorytmy wizualizacji danych) model terenu niesie informację archeologiczną, to jest ona bardzo ograniczona. W pobliżu Sławna łatwo można dostrzec kilka kurhanów, a zwłaszcza dominujący nad nimi nasyp o wysokości względnej sięgającej 5,5 m (jasna, okrągła plama na wschodzie). Jednakże na obrazie przedstawiającym rejon Polanowa (w rzeczywistości obfitujące w ukryte w lasach liczne ślady po przeszłej działalności człowieka) trudno zidentyfikować potencjalne obiekty archeologiczne. Specyfika tych obiektów w znaczący sposób może utrudnić ich rozpoznanie (opracowanie własne)

Fig. 8. Two DTMs. A vicinity of Sławno on the left and around Polanów on the right. Although 'bare' DTMs (not processed using any of the visualisation methods) contains archaeological information, it is not readable. In the vicinities of Sławno some burial mounds may be easily spotted - especially the monumental one, reaching 5.5 in height (bright spot to the east). However, in the image related to the vicinity of Polanów (in reality abundant in remains of past human activity hidden in the forest) the interpretation is difficult. Specific nature of potential archaeological objects might hamper the prospection (by Author) 
tencjalnie archeologiczne spośród niepoddanych antropopresji struktur morfologicznych. Należy przyznać, że wśród stosowanych w archeologii algorytmów nie ma jednego, który da się zastosować do analizy wszystkich obszarów (niezależnie od rzeźby terenu) lub do identyfikacji każdego rodzaju obiektów archeologicznych (bez względu na ich właściwości przestrzenne). Dopiero kombinacja odpowiednio dobranych narzędzi pozwala na bardziej wszechstronną identyfikację zasobów dziedzictwa archeologicznego na podstawie danych ALS. Zróżnicowane funkcje poszczególnych analiz ułatwiają i umożliwiają rozpoznanie m.in. przez: rozwiązanie problemu nasłonecznienia NMT z wybranej strony, usunięcie cienia, przewyższenie wartości wysokości, usunięcie wielkich bądź małych form krajobrazowych (w zależności od celu badawczego).

Podstawową metodą wizualizacji NMT/NMPT jest analiza cieniowania (ang. hillshade). Po pierwsze, polega ona na wygenerowaniu źródła światła znajdującego się poza analizowanym modelem terenu (o ściśle określonej wysokości kątowej oraz azymucie), które to przez wysłanie równoległych wiązek światła nadaje plastyczności analizowanym modelom (ryc. 9). Po drugie, różnice wysokości na NMT/NMPT powodują, iż np. jedna strona wzgórza jest oświetlona (możliwa jest identyfikacja

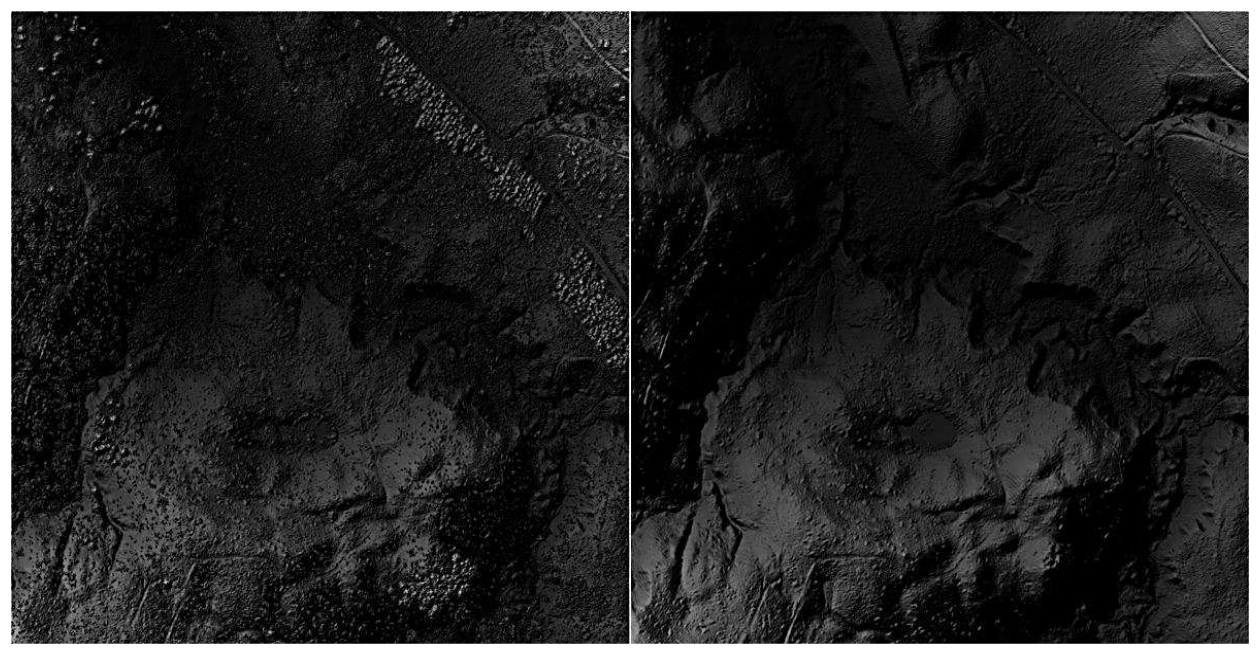

Ryc. 9. Z lewej: analiza cieniowania NMPT (źródło światła: wysokość $30^{\circ}$, azymut $310^{\circ}$ ), z prawej: analiza cieniowania NMT (źródło światła: wysokość $30^{\circ}$, azymut $310^{\circ}$ ). Uwagę zwracają duże obszary na południowo-wschodnich stokach ukryte $\mathrm{w}$ cieniu, uniemożliwiającym rozpoznanie potencjalnych obiektów archeologicznych. Na zachód od doliny rzecznej liczne kurhany, nieujawniające się na NMPT, a na NMT zakryte w niektórych wypadkach cieniem. Okolice Polanowa (opracowanie własne)

Fig. 9. A shaded DSM (light source height: $30^{\circ}$ and azimuth: $310^{\circ}$ ) on the left and a shaded DTM on the right (light source height: $30^{\circ}$ and azimuth: $310^{\circ}$ ). Attention has to be paid to extensive areas at the south-east slopes, which are hidden in the shade. This makes an interpretation of archaeological remains nearly impossible. To the west of the river valley a number of burial mounds is present. A vicinity of Polanów (by Author) 
zlokalizowanych na nim małych form krajobrazowych, w tym np. kurhanów), druga zaś pogrążona jest w cieniu (uniemożliwiającym jakiekolwiek rozpoznanie). Rozwiązanie tego problemu, czyli zmiana lokalizacji źródła światła w taki sposób, aby wirtualne słońce świeciło pod innym kątem niż za pierwszym razem, jest możliwe, dzięki czemu można uzyskać efekt doświetlenia wcześniej zaciemnionych obszarów. Jednak rozwiązanie to jest mało efektywne w przypadku złożonych struktur. Interpretacja obiektów liniowych, np. umocnień, dróg lub granic pól, niebiegnących w linii prostej, oraz ich skartowanie z koniecznością nieustannej zmiany oświetlenia jest uciążliwe i może być przyczyną błędów (wynikających z ,przesunięć” cienia interpretowanych obiektów). Po trzecie, skomplikowane ukształtowanie terenu może zupełnie uniemożliwić rozpoznanie małych form krajobrazowych na podstawie tej zasadniczej analizy (gdy nie ma możliwości „usunięcia” cienia z danego obszaru).

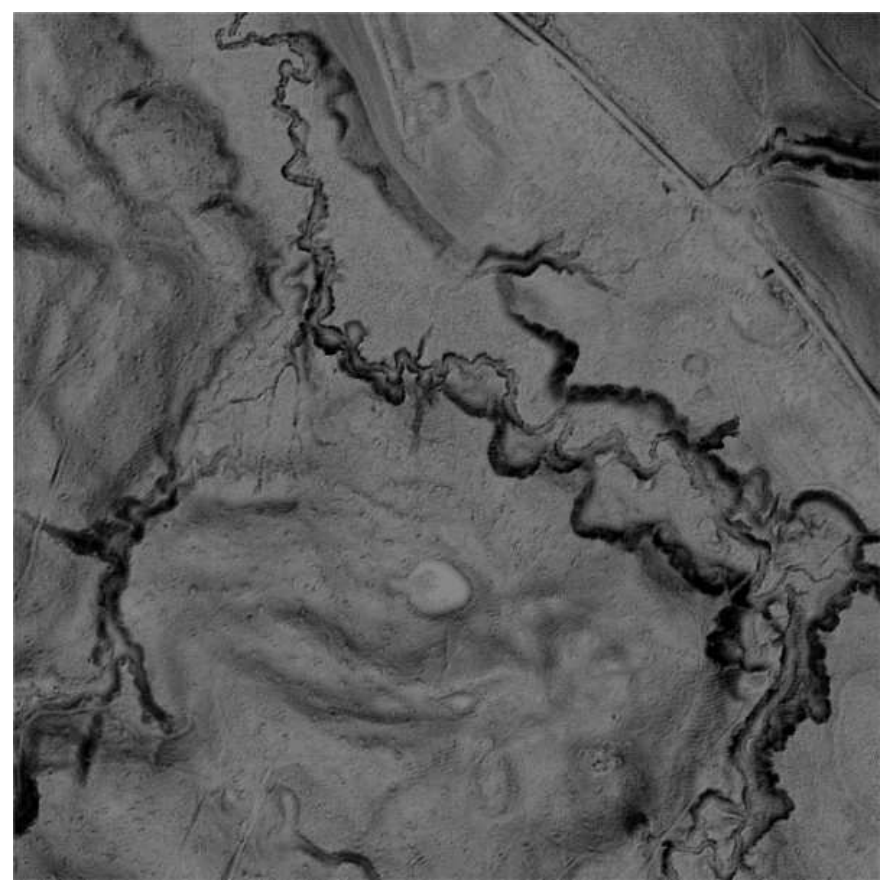

Ryc. 10. Analiza Sky-view Factor na NMT (min. promień: 1 m, maks. promień: 10 m, liczba kierunków: 32 , zakres wyświetlania 0,84-1). Uwagę zwraca brak cienia. Im jaśniejszy piksel, tym więcej hemisfery widocznej z danego punktu. Na zachód od doliny rzecznej liczne kurhany, ujawniające się jako drobne biało-czarne plamy, ze względu na ukształtowanie terenu i wielkość obiektów w niektórych wypadkach są one trudne do zidentyfikowania. Okolice Polanowa (opracowanie własne)

Fig. 10. Sky-view Factor analysis of a DTM (min. radius: $1 \mathrm{~m}$; max. radius $10 \mathrm{~m}$; No. of directions: 32; histogram stretch $0,84-1$ ). Interesting is the lack of shade. The brighter the pixel is, the more hemisphere is visible from a single point. Burial mounds located to the west of the river valley and visible as small black-white dots are in some cases hard to identify due to complicated terrain relief and objects' size. A vicinity of Polanów (by Author) 


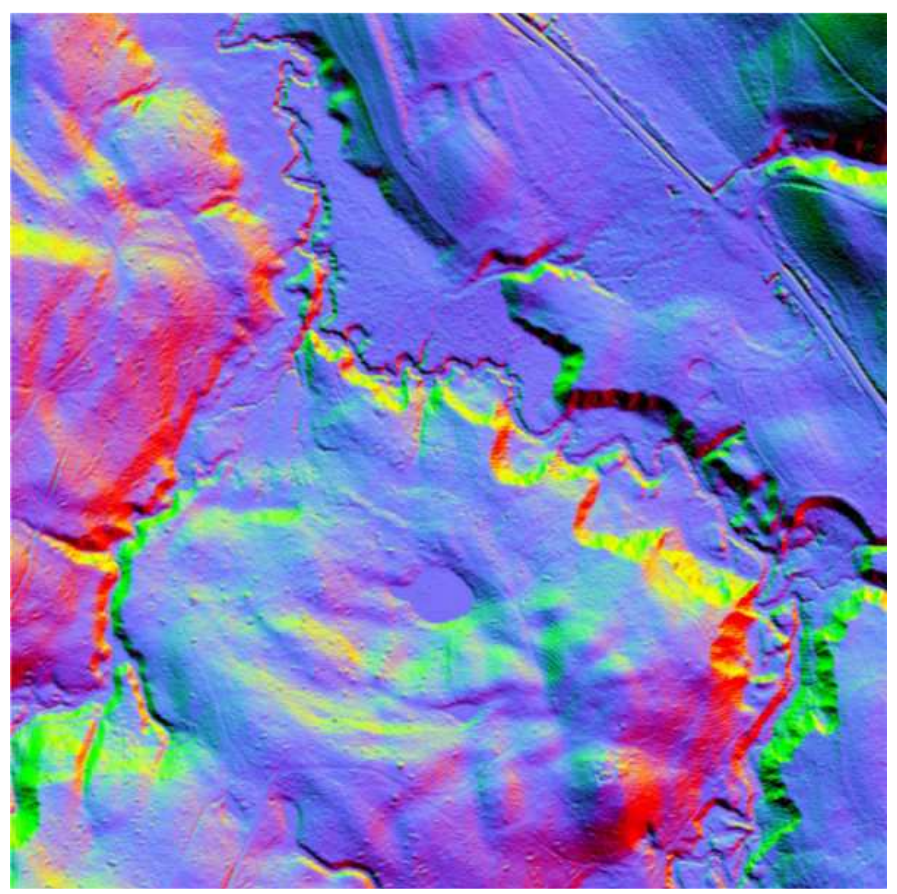

Ryc. 11. Analiza Principal Component Analysis na NMT (3 podstawowe komponenty 16-kierunkowej analizy cieniowania). Kanał ,czerwony” - komponent 1, kanał ,zielony” - komponent 2, kanał „niebieski" - komponent 3. Uwagę zwraca brak cienia. Na zachód od doliny rzecznej liczne kurhany. W niektórych partiach obszaru są one bardziej czytelne niż w analizie SVF, w innych zaś, ze względu na ostre przejścia pomiędzy kolorami interpretacja jest utrudniona. Okolice Polanowa (opracowanie własne)

Fig. 11. Principal Component Analysis of a DTM (first three components of a 16-direction shading) Red Channel $-1^{\text {st }}$ component, Green $-2^{\text {nd }}$ component and Blue $-3^{\text {rd }}$ component. Interesting is the lack of shade. Burial mounds located to the west of the river valley. In some parts of the image those mounds are visible more clearly than on the results of SVF analysis. In other parts though, due to sharp conversion between colours, the interpretation is hampered. A vicinity of Polanów (by Author)

Pośród różnych, zaawansowanych algorytmów wizualizacji NMT/NMPT, funkcjonujących powszechnie $\mathrm{w}$ archeologii światowej, należy zwrócić uwagę przede wszystkim na analizę Sky-view Factor ${ }^{68}$, przeliczającą zakres hemisfery dostępnej z danego miejsca na analizowanym modelu (ryc. 10), oraz Principal Component Analysis (PCA) ${ }^{69}$. PCA pozwala stworzyć barwny (RGB) obraz trzech najważniejszych komponentów analizy cieniowania, przeprowadzonej na 16 kierunkach naświetlania NMT/NMPT (ryc. 11). Niezwykle przydatna jest również analiza lokalnych różnic rzeźby terenu (ang. Local Relief Model), zaproponowana przez

${ }^{68}$ Zakšek, Oštir, Kokalj 2011.

${ }^{69}$ Devereux, Amable, Crow 2008. 
R. Hesse ${ }^{70}$. Bez wątpienia warte uwagi są algorytmy G. Millera ${ }^{71}$, ukazujące dostępność (otwartość) terenu, oraz S. Rusinkiewicza, M. Burnsa i D. DeCarlo ${ }^{72}$, pozwalające wyostrzyć cieniowanie. Zbiór stosowanych algorytmów uzupełniają m.in. Low Pass Filter, Trend Removal (ryc. 12), Local Dominance, Cumulative Visibility ${ }^{73}$.

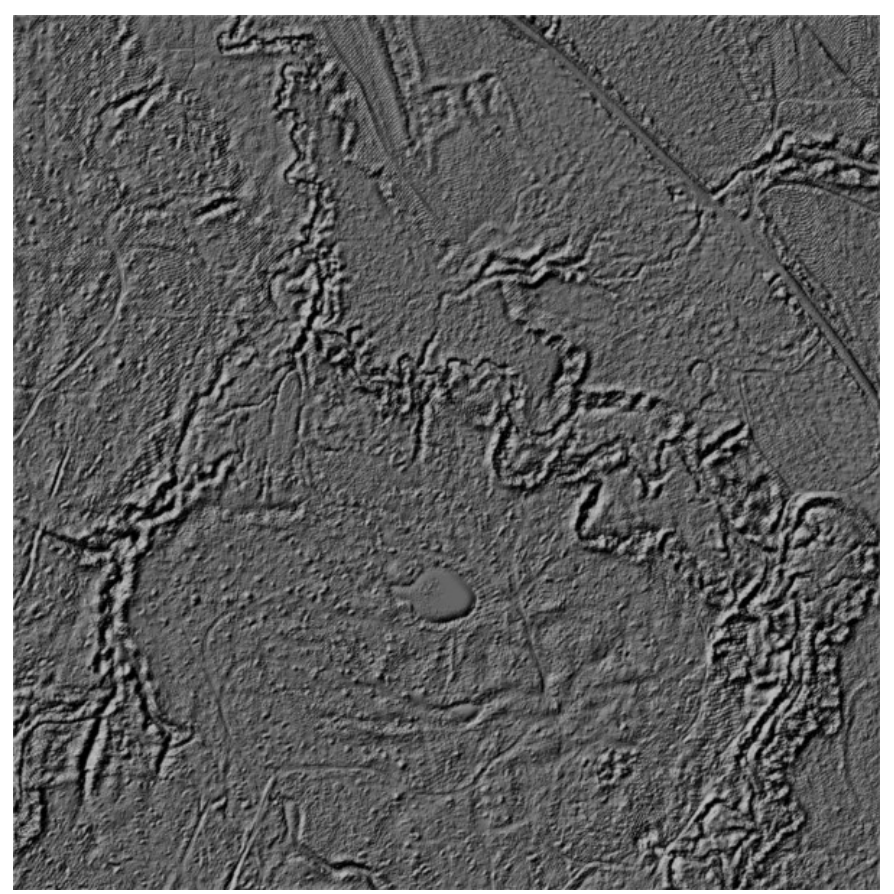

Ryc. 12. Analiza Trend Removal na NMT, zrównująca formy krajobrazowe o większym rozmiarze przestrzennym od przyjętego progu (w tym wypadku $12 \mathrm{~m}$ ). Dzięki temu obszar pozbawiony jest cienia owych form, a widoczne cieniowanie (źródło światła: wysokość $30^{\circ}$, kierunek $310^{\circ}$ ) związane jest wyłącznie z mniejszymi formami. Na zachód od doliny rzecznej liczne kurhany. Czytelność wyników analizy (podobnie jak wszystkich pozostałych) jest ściśle związana z jakością analizowanego NMT oraz rzeźby terenu. Kurhany, choć widoczne na „spłaszczonych” wzgórzach, są wizualnie zdominowane przez inne, naturalne formy geomorfologiczne. Okolice Polanowa (opracowanie własne)

Fig. 12. Trend Removal analysis of a DTM, which equals the landforms bigger than a set threshold (a radius $12 \mathrm{~m}$ in this case). Consequently the whole area is deprived of shading of these forms. Present shades are related only to smaller spatial objects (light source height: $30^{\circ}$ and azimuth: $310^{\circ}$ ). To the west of the river valley a number of burial mounds is present. Readability of the results (as in other cases) is strictly linked with the quality of the analysed DTM and the relief. Burial mounds, which are clearly seen at the top of flattered hills, are still dominated by other, natural forms. A vicinity of Polanów (by Author)

\footnotetext{
${ }^{70}$ Hesse 2010.

${ }^{71}$ Miller 1994.

${ }^{72}$ Rusinkiewicz, Burns, DeCarlo 2006.

${ }^{73}$ R. Hesse - informacja ustna.
} 
Porównania wyników różnych metod wizualizacji danych ALS w literaturze przedmiotu dokonali między innymi: Z. Kokalj, K. Zakšek, i K. Oštir ${ }^{74}$. Ich studia komparatystyczne ukazują, jak bardzo istotnym procesem jest wytworzenie produktów pochodnych analiz modeli terenu. Wyniki zastosowania jednego algorytmu mogą być zdecydowanie różne od rezultatów wykorzystania drugiego. Przez to efekty interpretacji poszczególnych zobrazowań odbiegają od siebie, wpływając w istotny sposób na kartowanie zidentyfikowanych obiektów archeologicznych. Ze względu na koszty uzyskania danych brak zastosowania funkcjonujących w archeologii światowej algorytmów przetwarzania modeli numerycznych należy uznać za nieefektywny. Dochodzi bowiem wówczas do znacznego ubytku informacji odnośnie do zasobu dziedzictwa.

\section{Poziom 4G. Interpretacja produktów analiz}

Poddane zróżnicowanym analizom produkty ALS-u są następnie interpretowane. Jak wspomniano, w archeologii europejskiej badacze eksplorujący zobrazowania lidarowe mają często zaplecze warsztatowe wypracowane na podstawie analiz i interpretacji zdjęć lotniczych (np. M. Doneus, S. Crutchley), a także dzięki zróżnicowanym projektom badawczym mieszczącym się w obrębie silnie rozwiniętej (zwłaszcza na Wyspach Brytyjskich) archeologii krajobrazu. Jednocześnie z powodu olbrzymiego zainteresowania wynikami pomiarów również i inni archeolodzy pragną uzyskiwać dane przestrzenne tą metodą. Jednakże doświadczenie interpretacyjne, nabyte podczas czytania zdjęć lotniczych, pozwala pełniej wykorzystać potencjał ALS-u na etapie interpretacji. Istnieje zagrożenie, iż w przypadku badaczy nieposiadających takiego doświadczenia aplikacja danych lidarowych może przypominać sytuację, jaka towarzyszyła zastosowaniu zdjęć lotniczych w polskiej archeologii ${ }^{75}$.

Produkty lotniczego skaningu laserowego to w pewnym sensie ,niebezpieczne dane". Ze względu na zakorzenione w kulturze traktowanie produktów kartograficznych (np. map) jako obiektywnego odwzorowania rzeczywistości, a także niepodważalną, choć wyłącznie w wybranych (najczęściej najbardziej spektakularnych) przypadkach łatwość w archeologicznej interpretacji NMT (np. wyraźnych grodzisk,

\footnotetext{
${ }^{74}$ Kokalj, Zakšek, Oštir 2012; Z. Kokalj, K. Oštir, T. Veljanovski i A. Kobler podczas konferencji „AARG International Aerial Archaeology Conference” (Bukareszt, 15-18.09.2010) w referacie Support of LiDAR advanced data visualizations in past cultural features recovery in vegetated areas: past water streams, bronze age hill forts, past settlements, WW1 trenches and shell craters przedstawili możliwość zastosowania zróżnicowanych algorytmów w identyfikacji obiektów archeologicznych, a R. Hesse na posterze Detecting former field systems with airborne LIDAR - an overview of current methods, zaprezentowanym podczas konferencji „AARG. Aerial Archaeology, Remote Sensing and the Archaeological Process" (Budapeszt, 13-15.09.2012), zwrócił uwagę na wyniki wykorzystania różnych rozwiązań analitycznych w prospekcji dawnych systemów uprawy.

${ }^{75}$ Np. Żuk 2005.
} 
kurhanów czy megalitów) można dać się „omamić” (ryc. 13). Z łatwością można uznać, że dane lidarowe mogą być bez większych problemów interpretowane przez wszystkich zainteresowanych, w tym nieposiadających jakiejkolwiek wiedzy na temat możliwości interpretacji zobrazowań teledetekcyjnych. Jeżeli opracowanie D.R. Wilsona ${ }^{76}$ można uznać za pierwszy krok w świadomym korzystaniu ze zdjęć lotniczych w archeologii, to w przypadku danych lidarowych (a szerzej: badań krajobrazowych) jako główne wprowadzenie do efektywnego zastosowania i pełniejszego czytania produktów ALS-u pretenduje praca zbiorowa pod redakcją D.C. Cowleya i R.S. Opitz ${ }^{77}$.

L. Żuk ${ }^{78} \mathrm{w}$ perswazyjny sposób przedstawiła problemy z aplikacją zdjęć lotniczych w Polsce. Pragnienie i potencjał wykorzystania zdjęć zostały skonfrontowane z niewłaściwymi sposobami ich uzyskiwania i interpretacji. Fenomen ujawniania się na zobrazowaniu lotniczym pewnych aspektów obiektów archeologicznych jest nie-

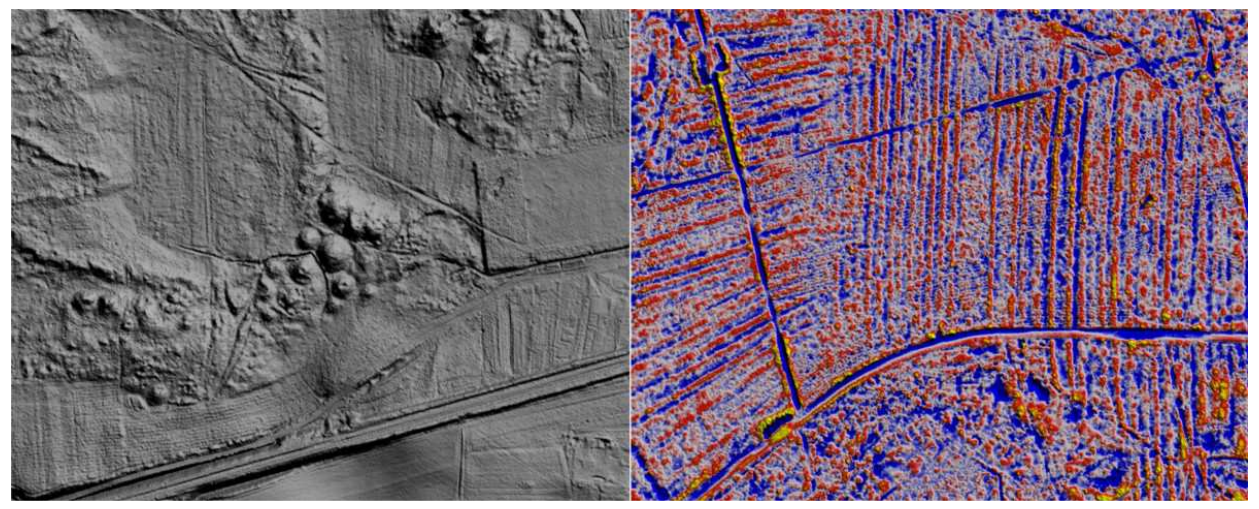

Ryc. 13. Spektakularne obiekty są wyraźnie widoczne na produktach ALS. Inaczej rzecz ma się z mniej ujawniającymi się. Po lewej: cmentarzysko kurhanowe. O ile duże nasypy są łatwe do identyfikacji, o tyle mniejsze ,gubią się" dla oka interpretatora wśród naturalnych form geomorfologicznych. Po prawej: układ pól (ujawniający się w postaci szeregów linii), który możliwy jest do wyróżnienia jedynie z zastosowaniem specjalistycznych algorytmów - w tym wypadku Local Relief Model (Hesse 2010). Niewielkie różnice w wysokości względnej oraz odmienne kierunki linii powoduja, iż układ ten jest niezwykle trudny do identyfikacji z wykorzystaniem prostych analiz (np. analizy cieniowania). Okolice Sławna (opracowanie własne)

Fig. 13. Spectacular structures are clearly visible at the products of ALS. Less exposed forms are less unambiguous. A mound cemetery at the left hand side. Although large mounds are easy to interpret, the small-sized could be lost by the interpreter. On the right a field system (seen as a palimpsest of lines), which may be enhanced only due to the use of advanced filters - in this case Local Relief Model analysis (Hesse 2010). Slight differences in attitude and diverse orientation of lines make that this system extremely hard to identify using only simple analysis (e.g. shaded relief). A vicinity of Sławno (by Author)

\footnotetext{
${ }^{76}$ Wilson 2000.

${ }^{77}$ Cowley, Opitz 2012.

${ }^{78}$ Żuk 2005.
} 
zwykle skomplikowany, a zatem podczas wykonywania i czytania fotografii konieczna jest specjalistyczna wiedza. A. Ciołkosz, J. Miszalski i J.R. Olędzki ${ }^{79}$ postulują, iż „interpretować zdjęcia mogą tylko specjaliści od określonych zagadnień” ${ }^{\circ 0}$. Jednak w przypadku archeologii zarówno proces wykonywania fotografii, jak i ich analiz oraz interpretacji był często zlecany innym badaczom, wykorzystującym je w swojej praktyce, np. geografom ${ }^{81}$. Badacze pozbawieni wiedzy specjalistycznej, niezbędnej do archeologicznego czytania zdjęć, nie byli w stanie rozpoznać na nich śladów po przeszłej działalności człowieka, ujawniających się w postaci rozmaitych wyróżników. Ta nieumiejętność interpretacji (a nie ograniczenia metody) spowodowała spadek zainteresowania możliwościami wykorzystania fotografii lotniczych, a w konsekwencji ograniczenie liczby ich zastosowań w polskich projektach badawczych ${ }^{82}$.

Istnieje zagrożenie, że z podobną sytuacją można się spotkać w kontekście aplikacji lidaru w Polsce. Bez odpowiedniego doświadczenia i wiedzy dotyczącej czytania produktów ALS-u, a także rozumienia subiektywności procesów obróbki i natury danych, może dojść do znacznego ubytku informacji. Jeżeli interpretację pochodnych NMT będą prowadzić zespoły badawcze nieprzygotowane do pełnego wykorzystania potencjału danych lidarowych (w pewnym sensie zamknięte w badaniach nad konkretnym tematem), to redukcja może być znacząca. Jak pokazuje dotychczasowa praktyka aplikacji produktów ALS-u w polskiej archeologii, pomiary zostały przeprowadzone przez zespoły, które w głównej mierze można „przypisać” do danej epoki w pradziejach. Widać to wyraźnie w określonych celach badawczych. Badacze zajmujący się epoką kamienia poszukiwali grobowców megalitycznych ${ }^{83}$ lub kopalń krzemienia ${ }^{84}$. Prowadzący studia nad średniowieczem skupili się dotychczas na grodziskach czy cmentarzyskach kurhanowych, pochodzacych z wieków średnich ${ }^{85}$, zainteresowani zaś epoką brązu próbowali zidentyfikować kurhany ze środkowej epoki brązu ${ }^{86}$.

\footnotetext{
${ }^{79}$ Ciołkosz, Miszalski, Olędzki 1999, 141, 142.

${ }^{80}$ Za: Żuk 2005, 133.

${ }^{81}$ Żuk 2005, 129-133.

${ }^{82}$ Żuk 2005, 137.

${ }^{83}$ Referat A. Przybył i M. Furmanka Zapomniane cmentarzyska. Badania nieinwazyjne a ochrona dziedzictwa archeologicznego terenów zalesionych na przykładzie Lasu Muszkowickiego podczas konferencji „Metody geofizyczne w archeologii polskiej. Spotkanie II”, Poznań, 22-23.11.2012.

${ }^{84}$ Badania W. Migala (Państwowe Muzeum Archeologiczne), R. Zapłaty i J. Budziszewskiego (Uniwersytet Kardynała Stefana Wyszyńskiego).

${ }^{85}$ Badania M. Wyczółkowskiego i Muzeum im. Wojciecha Kętrzyńskiego w Kętrzynie oraz referat C. Sobczaka An Experimental Application of Airborne Laser Scanning for Landscape Archaeology in Northeastern Poland podczas konferencji „AARG. Aerial Archaeology, Remote Sensing and the Archaeological Process”, Budapeszt, 13-15.09.2012.

${ }^{86}$ Poster J. Czebreszuka, M. Jaegera, Ł. Pospiesznego, J. Kneisel, M. Cwalińskiego, J. Niebieszczańskiego, M. Stróżyka Badania nieinwazyjne kurhanów z epoki brąu podczas konferencji „Metody geofizyczne w archeologii polskiej. Spotkanie II”, Poznań, 22-23.11.2012.
} 
Truizmem będzie stwierdzenie, iż takie rozwiązanie problemu ma swoje zarówno dobre, jak i złe strony. Warto je jednak przybliżyć. Za korzystne należy uznać precyzyjne określenie celu badań ściśle związanego z własnymi zainteresowaniami archeologów. Jako specjaliści w danym zakresie kulturowo-historycznym znają oni dobrze rodzaje obiektów archeologicznych, charakterystycznych dla danej epoki czy danego kręgu kulturowego, i są w stanie przewidzieć, jakiego rodzaju obiektów mogą spodziewać się podczas oglądu modeli numerycznych. Odnosi się to do kształtów i rozmiarów obiektów archeologicznych, a także zróżnicowanych aspektów ich topologii - orientacji, lokalizacji względem siebie bądź struktur geomorfologicznych. Jednak ograniczenie kulturowo-historyczne powoduje zagrożenie, iż owi badacze nie będą w stanie rozpoznać obiektów archeologicznych pochodzących z innych horyzontów kulturowych, współwystępujących na jednym obszarze, a nawet pominięcie nieznanych typów obiektów z badanego okresu. Nieznajomość zróżnicowanych form krajobrazowych, np. skomplikowanych kształtów związanych z historyczną uprawą pól, może spowodować, że potencjał wykonanych pomiarów ALS nie zostaje w pełni wykorzystany, gdyż nierozpoznane obiekty nie zasilą zasobu informacji o dziedzictwie archeologicznym danego regionu.

Nie odnosząc się krytycznie do powyżej wymienionych projektów (ze względu na początkową fazę opracowań nie ma podstaw do krytyki), należy zwrócić uwagę na zagrożenia, jakie niosą ,wąskie” (np. w sensie chronologicznym) zainteresowania badawcze oraz nieznajomość możliwości interpretacji wszystkich obiektów potencjalnie ujawniających się na zobrazowaniach lidarowych. Trudno oczekiwać bowiem, iż wszyscy zainteresowani wykorzystaniem ALS-u w badaniach archeologicznych zgłębią każdą tajemnicę czytania danych.

\section{Poziom 6. Tworzenie zasobu informacji ostatecznie wykorzystanych do konstrukcji obrazu przeszłości}

Na podstawie interpretacji NMT i jego pochodnych nie można stwierdzić z całą stanowczością, iż rozpoznany na produktach ALS-u potencjalny obiekt archeologiczny ma charakter antropogeniczny i niewspółczesne pochodzenie. Choć istnieją elementy dziedzictwa, które ujawniają się szczególnie wyraźnie w danych przestrzennych, np. grodziska czy niektóre cmentarzyska kurhanowe, to większość zidentyfikowanych potencjalnych obiektów musi zostać zweryfikowana w terenie. Jest to konsekwencja omówionego charakteru danych przestrzennych, jak i form obiektów archeologicznych, często zbliżonych do struktur geomorfologicznych, przyrodniczych i innych.

Oprócz niezbędnej weryfikacji w terenie wyników interpretacji danych możliwa jest także weryfikacja gabinetowa. Jednakże wymaga ona doświadczenia z zakresu interpretacji zdjęć lotniczych. Dzięki uzyskaniu pionowych fotografii lotniczych pod- 


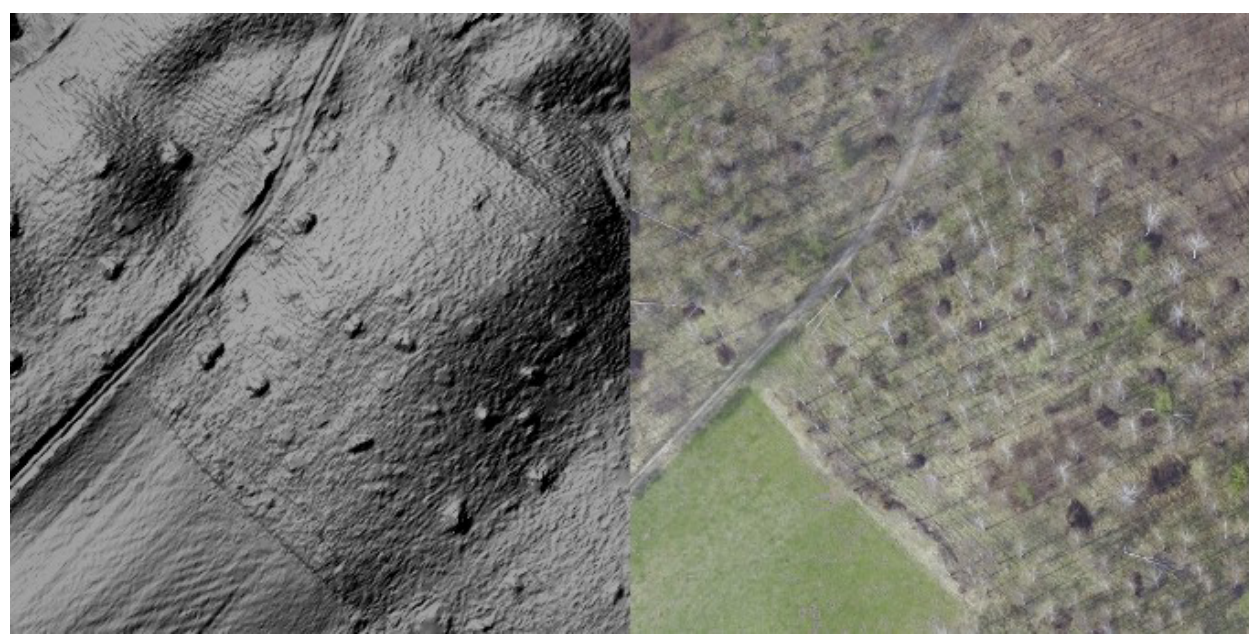

Ryc. 14. Weryfikacja analizy cieniowania NMT na podstawie uzyskanej jednocześnie ortofotomapy. Widoczne na NMT obiekty o kształcie zbliżonym do kurhanów są w rzeczywistości skupiskami chrustu, powstałymi podczas przecinki lasu. Okolice Sławna (opracowanie własne)

Fig. 14. Verification of shaded DTM on the basis of an orthophotomap. Structures resembling burial mounds and visible on the DTM are in reality just concentrations of brushwood. A vicinity of Sławno

(by Author)

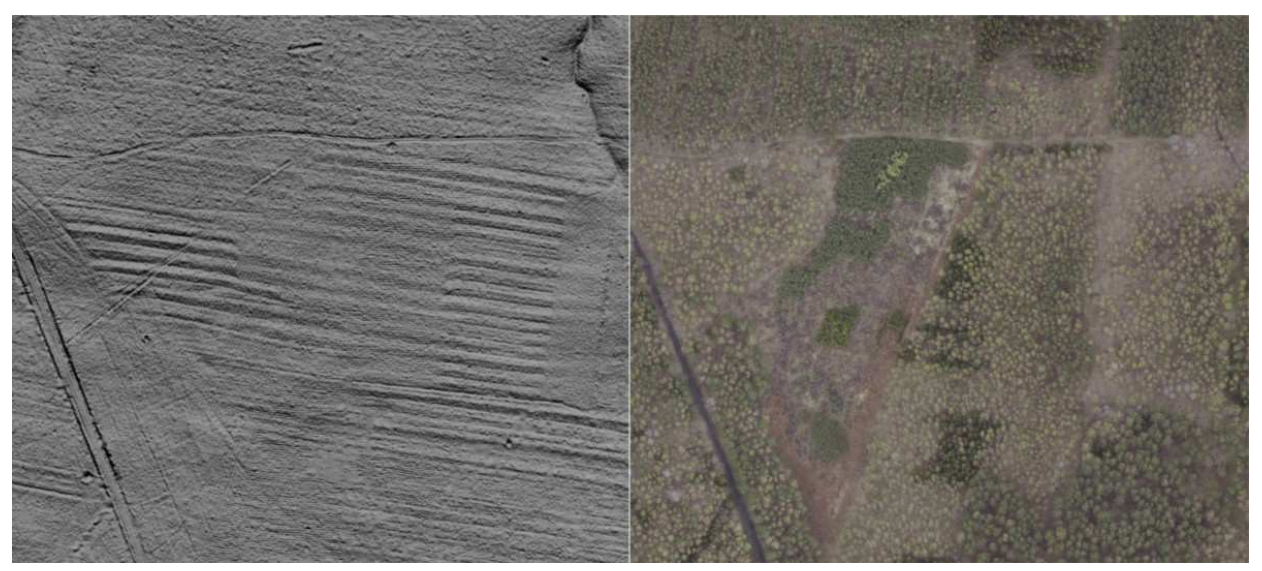

Ryc. 15. Weryfikacja analizy cieniowania NMT na podstawie pozyskanej jednocześnie ortofotomapy. Widoczne na NMT równoległe linie, biegnące na osi wschód-zachód z odchyleniem ku północy powstały wskutek prowadzonej w przeszłości orki. Doszło do zmiany zagospodarowania terenu i przeznaczeniu tego obszaru pod produkcję leśną. Orientacja śladów po przeszłych pracach rolnych jest odmienna od współczesnego kierunku orki pod las (zbliżonego do południkowego) i zostały one w znaczący sposób zniszczone przez współczesne zagospodarowanie terenu. Okolice Sławna, opracowanie własne

Fig. 15. Verification of shaded DTM on the basis of an orthophotomap. Parallel lines visible on the DTM, oriented more or less east-west were created during ploughing in the past. A change of land-use has occurred and this area was designated to forestation. The orientation of these remains is opposite to the present ploughing used in forestry and were partially disturbed by later land-use. A vicinity of Sławno (by Author) 
czas skaningu i przetworzeniu ich do ortofotomapy, uzyskiwana jest dodatkowa warstwa informacyjna, dotycząca bieżącego (aktualnego dla przelotu) stanu zagospodarowania przestrzennego obszaru badań (ryc. 14). Dzięki niej możliwe jest m.in. rozróżnienie potencjalnych kurhanów od skupisk chrustu, powstałych podczas przecinki lasu, lub rozpoznanie współczesnego kierunku orki na polach bądź w lasach, często odmiennego od form powstałych wskutek historycznych prac rolnych (ryc. 15). Również analiza map historycznych pozwala w niektórych wypadkach na określenie charakteru, funkcji i chronologii wybranych potencjalnych obiektów archeologicznych. Taka weryfikacja danych lidarowych w znaczący sposób może ograniczyć koszty oraz liczbę wyjazdów w teren.

$\mathrm{W}$ interpretacji danych pochodzących z pomiarów ALS prace terenowe są konieczne. Badania weryfikacyjne pozwalają często określić, czy wybrany potencjalny obiekt archeologiczny nie jest przypadkiem skupiskiem roślinności i tym samym zupełnie nie wiąże się z rzeźbą terenu. Dotyczy to zarówno obiektów punktowych, liniowych, jak i całych powierzchni. Z uwagi na trudność poruszania się $w$ lesie takie badania weryfikacyjne nie powinny być prowadzone bez wyposażenia w odbiorniki systemów nawigacji satelitarnych, ułatwiających nawigację, śledzenie i kartowanie zweryfikowanych pozytywnie obiektów. Poza tym ze względu na częsty brak pewności, czy dany obiekt powstał w wyniku przeszłej działalności człowieka, rozwiązania tego problemu należy szukać w wykorzystaniu innych nieinwazyjnych metod prospekcji archeologicznej lub nawet badań inwazyjnych. Choć zastosowanie metod magnetycznej, elektrooporowej czy georadaru w pewnych wypadkach może być niemożliwe do przeprowadzenia (ze względu na warunki morfologiczno-przyrodnicze wybranych obszarów), wyniki takich prac zdecydowanie poprawiają możliwości weryfikacji produktów interpretacji danych $\mathrm{ALS}^{87}$.

Tworzenie zasobu informacji ostatecznie wykorzystanych do konstrukcji zasobu dziedzictwa archeologicznego i związana z nimi końcowa redukcja informacji są rezultatem uznania danego potencjalnego obiektu za archeologiczny:

- wyłącznie dzięki interpretacji danych ALS (gdy nie dochodzi do weryfikacji terenowej)

lub

- na podstawie „pobieżnych” oględzin w terenie i klasyfikacji danego obiektu jako archeologicznego, po arbitralnym osądzie (wynikającym z doświadczenia badawczego), lecz bez wykorzystania innych metod prospekcji lub

- przez zastosowanie pozostałych metod prospekcji nieinwazyjnej (np. metodą magnetyczną, elektrooporową, analizy zdjęć lotniczych) lub badań inwazyjnych (odwierty, sondaże, regularne badania wykopaliskowe).

\footnotetext{
${ }^{87}$ Np. Kobyliński, Borowski, Budziszewski et al. 2012.
} 
W zależności od przyjętego rozwiązania zmianie ulega liczba oraz charakter zredukowanych informacji ${ }^{88}$. Par excellence rodzaj zasobu informacji tworzonych podczas badań wykorzystujących ALS pozostaje bez zmian. Składa się on ze zróżnicowanych map, zestawień i raportów, związanych pośrednio z subiektywnością uzyskanych danych przestrzennych, bezpośrednio wynika zaś z celów badawczych i wybranych sposobów przedstawienia danych.

\section{PODSUMOWANIE}

Rozwój technologii lidarowej, a wraz z nią metody lotniczego skaningu laserowego, w ciągu ostatnich kilkunastu lat nabrał tempa. W związku z tym dane uzyskane drogą ALS nie tylko znalazły zastosowanie na wielu polach ludzkiej działalności, lecz także znacząco zmieniły niektóre dziedziny życia. Spektakularne wyniki pomiarów przyniosły wiele rozwiązań i znacząco wpłynęły na efektywność pracy w zróżnicowanych aspektach. Archeologia, a zwłaszcza archeologia krajobrazu, jest bezdyskusyjnie jedną $\mathrm{z}$ beneficjentek rozwoju metod teledetekcyjnych. Potencjał prospekcyjny lotniczego skaningu laserowego pozwala badaczom przeszłości wkroczyć na przestrzennie nowe pola badawcze, dotychczas pozostające poza możliwościami tradycyjnego rozpoznania. Umożliwia także weryfikację wcześniejszych wyników badań oraz zwiększenie dokładności pomiaru i opisu obiektów archeologicznych (dotyczących ich liczby, kształtu, orientacji, lokalizacji). Ponadto zasób dziedzictwa objętego ochroną konserwatorską zostaje powiększony, a metody ochrony mogą być bardziej efektywne dzięki monitoringowi stanu zachowania stanowisk archeologicznych.

Opracowane dane lidarowe oferują znacznie więcej niż rozpoznanie obiektów archeologicznych czy możliwość ich ochrony. Umożliwiają one zmianę myślenia o przeszłym krajobrazie, wypełniając znaczeniowo pustą przestrzeń między dotychczasowymi punktowo określanymi stanowiskami archeologicznymi. Uzyskiwana dzięki temu ciągłość krajobrazu kulturowego, w którym obok elementów typowo wynikających z działalności człowieka są również i te „naturalne”, którym nadawane były zróżnicowane treści. Taki obraz krajobrazu przeszłości pozwala podjąć studia nad ludzką aktywnością, której aspektami są widoczność w terenie, poruszanie się czy ograniczanie dostępu. Rozpoznane dzięki pomiarom ALS, przenikające się oraz współwystępujące ślady po przeszłej działalności człowieka pokazują skomplikowany charakter osadnictwa i przetwarzania krajobrazu.

Autor niniejszego artykułu chciał zwrócić uwagę na etapy redukcji informacji, które towarzyszą wykorzystaniu ALS-u w badaniach archeologicznych. Entuzjazm

\footnotetext{
${ }^{88}$ Należy pamiętać, iż wraz z wykorzystaniem innych metod prospekcji badacze na nowo przechodzą przez poziomy redukcji informacji, charakterystyczne dla wybranej metody.
} 
zastosowania danych lidarowych, wynikający z ich olbrzymiego potencjału poznawczego, nie powinien przesłonić potrzeby krytycznych rozważań nad naturą produktów skaningu. M. Doneus i C. Briese ${ }^{89}$ zwracają uwagę, że istnieje niebezpieczeństwo braku zainteresowania metainformacjami dotyczącymi fenomenu danych (dającymi odpowiedzi m.in. na następujące pytania: Dlaczego dane są takie, a nie inne? $\mathrm{Z}$ czego wynika ich charakter? Dlaczego to, co widać, jest widoczne w taki, a nie inny sposób?). ,Z powodu braku wiedzy o technologii, algorytmach oraz metadanych, ALS staje się czymś w rodzaju «czarnej skrzynki», a wygenerowany NMT jest wykorzystywany bez najmniejszego krytycyzmu, zaś archeologiczny potencjał oraz ograniczenia danych lidarowych pozostają poza rozważaniami”, ${ }^{90}$.

Aspekty uzyskania danych (np. przyjęta metodyka pomiaru oraz możliwości fizyczne skanerów) i sposoby ich przetwarzania (np. algorytmy związane z klasyfikacją chmury punktów, łączeniem szeregów skanowania, filtracją danych na potrzeby wygenerowania NMT i NMPT oraz wizualizacją produktów pochodnych) są niezwykle istotne. Ich efektywne wykorzystanie wraz z ustawieniem parametrów skaningu dla celów archeologicznych pozwala (w pewnym zakresie) na ograniczenie redukcji informacji, charakterystycznej dla procedury wykorzystania danych lidarowych $^{91}$. W niniejszym tekście starano się pokazać, że chociaż na każdym etapie procedury obróbki, analiz i interpretacji danych dochodzi do strat, to od indywidualnych badaczy zależy sposób ograniczenia tego procesu przez wykorzystanie jak największej liczby dostępnych narzędzi i rozwiązań. Ominięcie bądź brak kontroli nad którymkolwiek z opisanych etapów przetwarzania danych spowoduje bowiem często nieodwracalne i negatywne skutki dla zasobów dziedzictwa i wiedzy o nim. Ponadto uwagę zwraca niezwykła bliskość interpretacji produktów ALS-u oraz fotografii lotniczych. Doświadczenie zdobyte podczas analiz zdjęć lotniczych pozwala zminimalizować stratę informacji na etapie interpretacji danych.

Istotnym niebezpieczeństwem jest traktowanie produktów lidarowych jako obiektywnych, pełnych i ostatecznych danych na temat wybranego obszaru. To zagrożenie jest szczególnie wyraźne podczas wykorzystywania danych przestrzennych pobranych dla innych celów niż archeologiczne. Jak słusznie wykazali J. Budziszewski i J. Wysocki ${ }^{92}$, wraz z realizacją się projektu „Informatyczny system osłony kraju przed nadzwyczajnymi zagrożeniami” (ISOK) wzrastają możliwości powszechnego wykorzystania danych ALS przez archeologów w Polsce. Zainaugurowany 30 lipca 2010 r., został on stworzony w celu poprawy bezpieczeństwa Polski

\footnotetext{
${ }^{89}$ Doneus, Briese 2011, 59.

${ }^{90}[\ldots]$ due to a lack of knowledge about underlying technology, algorithms, and metadata, ALS becomes a kind of 'black box', where the derived DTM is used without source criticism, and the archaeological potential and limitation of the ALS data again remain unconsidered" (Doneus, Briese 2011, 59).

${ }^{91}$ Nie dotyczy to jednak niezwykle ważnego, aczkolwiek często nieuświadamianego sobie, redukcyjnego charakteru myślenia archeologów.

${ }^{92}$ Budziszewski, Wysocki 2012, 123.
} 
w odniesieniu do zagrożeń naturalnych, a w szczególności do zmniejszenia zagrożenia powodziowego i ograniczenia jego skutków. Zadanie to ${ }^{93}$ ma osiągnąć swoje cele przez opracowanie m.in. map ryzyka powodziowego, map zagrożeń meteorologicznych, map innych zagrożeń oraz map hydrograficznych Polski i udostępnienie tych produktów społeczeństwu przez specjalny, nowoczesny system informatyczny ISOK $^{94}$. Wśród zróżnicowanych produktów projektu, z archeologicznego punktu widzenia, należy zwrócić szczególną uwagę na oferowane (generowane na podstawie lotniczego skaningu laserowego) chmury punktów oraz modele terenu.

Za uzyskanie danych ALS oraz stworzenie NMT/NMPT w ramach ISOK-u odpowiedzialny jest Główny Urząd Geodezji i Kartografii (GUGiK). Całość skanowanego obszaru (204 $320 \mathrm{~km}^{2}$, czyli blisko $2 / 3$ powierzchni kraju) została podzielona na różne standardy ${ }^{95}$. Na tej podstawie wygenerowane zostają trzy rodzaje NMT i NMPT ${ }^{96}$. Obszar planowanego zasięgu opracowania danych ALS w ramach projektu przedstawiono na rycinie 16. Na bieżąco z postępującym opracowaniem produkty są dodawane do Państwowego Zasobu Geodezyjnego i Kartograficznego (ryc. 17). Są one wówczas dostępne dla każdego odbiorcy - za opłatą, którą, biorąc pod uwagę koszty uzyskania danych lidarowych, z całą pewnością należy uznać za drobną ${ }^{97}$.

Wykonanie pomiarów ALS dla 2/3 powierzchni kraju i udostępnienie danych w ramach kosztów umożliwiających ich szerokie zastosowanie w wielu dziedzinach mogą i powinny zostać wykorzystane przez polskich archeologów. Ich dostępność powinna wpłynąć na wzrost liczby projektów, w których wykorzystywane byłyby dane lidarowe w identyfikacji nowych obiektów archeologicznych, weryfikacji dotychczasowej wiedzy o znanych stanowiskach oraz stać się punktem wyjścia do niezbędnego monitoringu stanowisk w celu ich ochrony. Jednocześnie, opracowując dane pochodzące z projektu ISOK, należy mieć świadomość, że nie zostały one ani uzyskane, ani przetworzone dla celów archeologicznych. $Z$ tego powodu na każdym z wymienionych w artykule etapów realizacji badań nad przeszłością z wykorzystaniem

\footnotetext{
${ }^{93}$ Realizowane przez konsorcjum, w skład którego wchodzi Instytut Meteorologii i Gospodarki Wodnej - Państwowy Instytut Badawczy, Krajowy Zarząd Gospodarki Wodnej, Główny Urząd Geodezji i Kartografii (GUGiK), Instytut Łączności - Państwowy Instytut Badawczy oraz Rządowe Centrum Bezpieczeństwa. Źródło: http://isok.imgw.pl [dostęp: 01.08.2013].

${ }^{94}$ Źródło: http://isok.imgw.pl [dostęp: 01.08.2013].

${ }^{95}$ Zgodnie z tym podziałem, skanowaniu w pierwszym standardzie - o gęstości pomiaru rzędu 4 i 6 punktów $/ \mathrm{m}^{2}$ - podlegają obszary odpowiednio $182403 \mathrm{~km}^{2}$ i $8148 \mathrm{~km}^{2}$, w drugim zaś - o gęstości 12 punktów pomiarowych/m² - obszary miejskie o powierzchni $13769 \mathrm{~km}^{2}$. Źródło: http://www.gugik. gov.pl/projekty/isok [dostęp: 01.08.2013].

${ }^{96}$ Pierwszy w jednolitym standardzie dla całości opracowania - GRID o oczku $1 \mathrm{~m}^{2}$; drugi dla obszarów z pierwszego standardu gęstości - GRID o oczku $1 \mathrm{~m}^{2}$, trzeci zaś dla obszarów z drugiego standardu gęstości - GRID o oczku 0,5 $\mathrm{m}^{2}$. Źródło: http://www.gugik.gov.pl/projekty/isok [dostęp: 01.08.2013].

${ }^{97}$ W 2013 r. wynosi ona 20 zł brutto za arkusz danych. Źródło http://www.codgik.gov.pl/zasob [dostęp: 01.08.2013].
} 


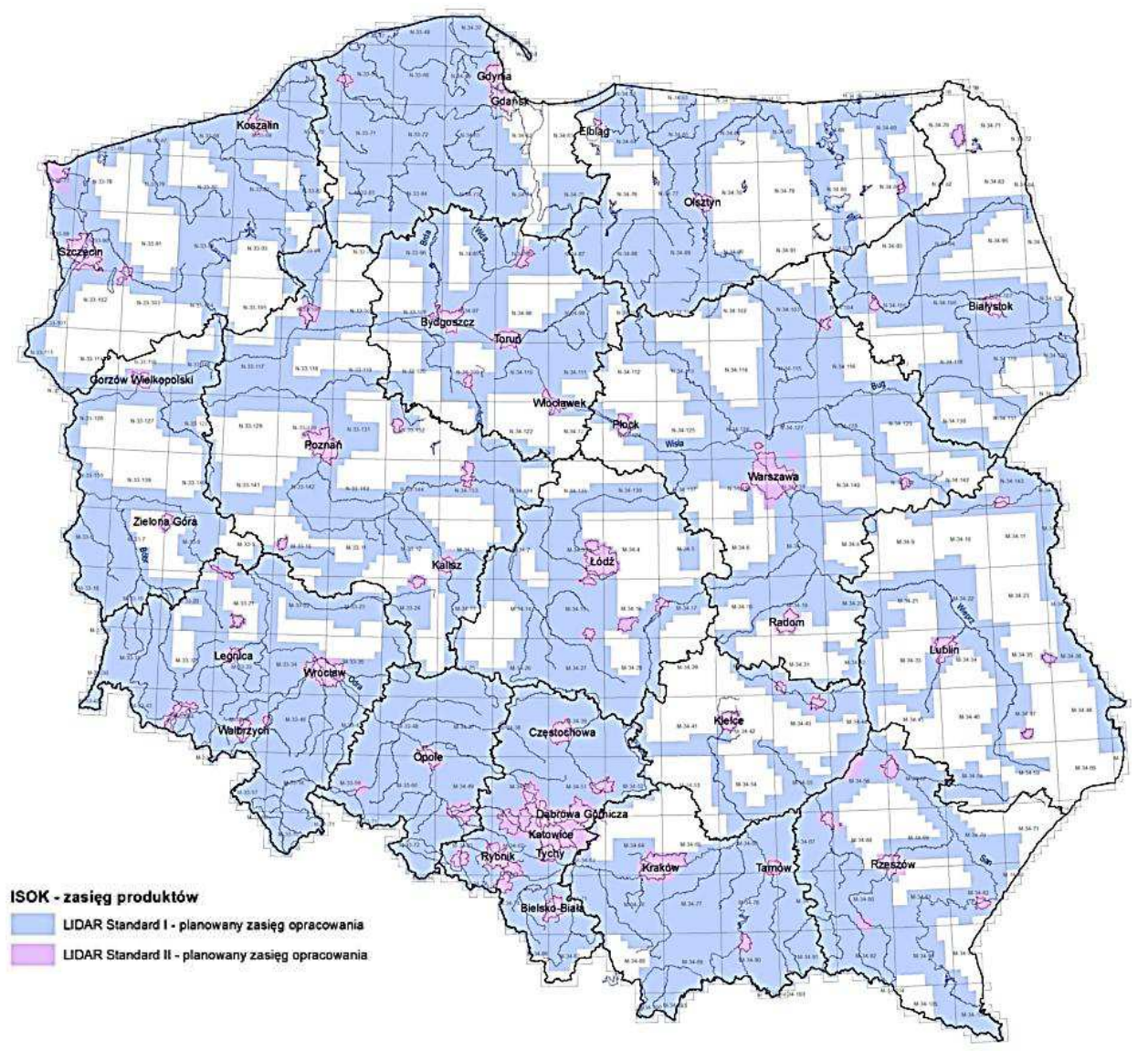

Ryc. 16. Obszar planowanego zasięgu opracowania danych ALS w ramach projektu ISOK (źródło: www.gugik.gov.pl)

Fig. 16. The area planned to be measured using ALS within the ISOK project (source: www.gugik.gov.pl)

korzystaniem danych ALS dochodzi do znaczącej redukcji informacji archeologicznej. Nie oznacza to, iż produkty ISOK-u nie są przydatne i nie mogą być użyte $\mathrm{w}$ praktyce badawczej. Wręcz przeciwnie - mogą być zastosowane $\mathrm{w}$ jak największej liczbie projektów i programów, jednak nie należy ich uznawać za pewną, ostateczną i obiektywną informację o badanym terenie.

Znajomość metod przetwarzania produktów skaningu pozwala na pewne ograniczenie procesów redukcji informacji archeologicznej, towarzyszącej przetwarzaniu danych na potrzeby ISOK-u. Dlatego najważniejszym produktem dla badaczy przeszłości, pragnących wykorzystać ten zasób, powinna być chmura punktów (jako najbardziej „surowy” z udostępnianych produkt skaningu), a nie wygenerowane modele numeryczne. Własne przetwarzanie danych lidarowych pozwala bowiem do- 


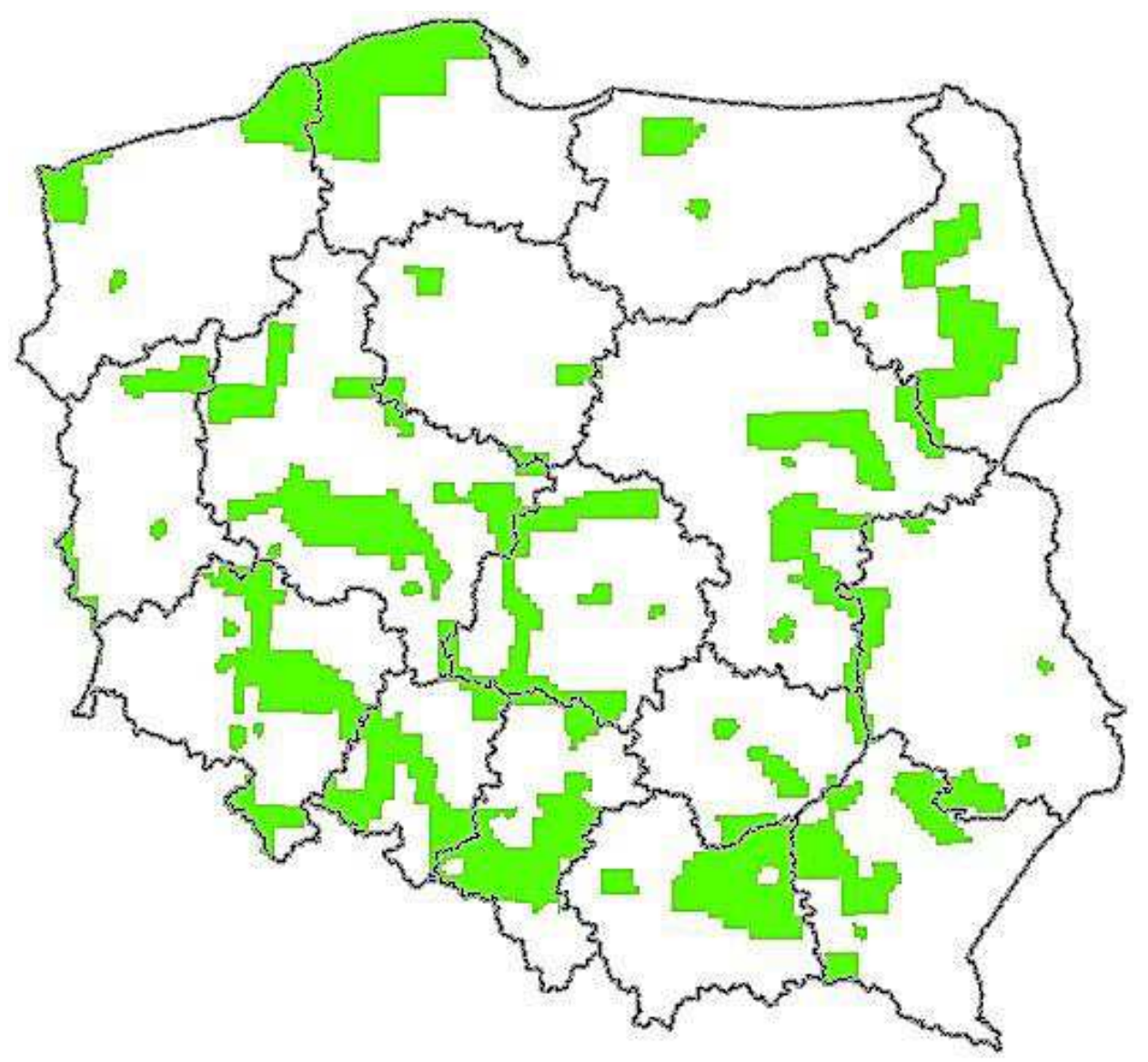

Ryc. 17. Produkty ISOK-a dostępne w Państwowym Zasobie Geodezyjnym i Kartograficznym. Stan na 01.08.2013 (źródło: www.gugik.gov.pl)

Fig. 17. Available ISOK products from Państwowy Zasób Geodezyjny i Kartograficzny. Date: 01.08.2013 (source: www.gugik.gov.pl)

trzeć do poziomu 4D i ograniczyć wszystkie procesy redukcji informacji, następujące wskutek klasyfikacji chmury punktów oraz kolejnych etapów. Poprzez reklasyfikację punktów dla celów archeologicznych i kolejne kroki przetwarzania danych możliwe jest uwypuklenie potencjalnych śladów po przeszłej działalności człowieka. W związku z tym do etapów utraty informacji, których nie można zminimalizować, zalicza się: określenie obszaru skaningu, wybór parametrów przelotu i procesy związane z powstaniem chmury punktów (np. nadanie georeferencji i wyrównanie szeregów). Choć na sposób uzyskania danych archeolodzy nie mogą mieć już wpływu, gdyż „samoloty już odleciały”, to wciąż możliwe jest wydobycie informacji archeologicznej na kolejnych etapach przetwarzania danych. Może tak się stać wyłącznie przez poznanie natury danych, uświadomienie sobie ich subiektywnego 
charakteru oraz znajomość metod przetwarzania danych. Kwestie zaś związane $\mathrm{z}$ interpretacją oraz weryfikacją wyników opracowania w takim samym stopniu dotyczą danych uzyskanych specjalnie dla celów archeologicznych, w ramach projektu ISOK czy pochodzących z innego źródła.

Wraz z powszechnym wykorzystaniem danych lidarowych $w$ archeologii europejskiej postępuje także ich zastosowanie $\mathrm{w}$ badaniach prowadzonych $\mathrm{w}$ Polsce. Zagrożeniem dla krajowej archeologii jest to, że aplikacja ALS-u może mieć znamiona klasycznego procesu wdrażania nowej technologii do danej dziedziny, gdy entuzjazm przesłania zdystansowane, pełne krytycyzmu podejście. Istnieje niebezpieczeństwo, że traktując lotniczy skaning laserowy jako doskonałą metodę prospekcyjną nie zwróci się uwagi na nieobiektywny charakter danych, skomplikowane metody ich przetwarzania, a także aspekty związane z generalizacją i reprezentacją rzeczywistości. Istnieją liczne powiązania zobrazowań lidarowych oraz zdjęć lotniczych, ujawniające się w subiektywności danych czy zbliżonym sposobie ich uzyskania. Należy jednak zwrócić uwagę na zagrożenie w potraktowaniu produktów ALS-u w podobny sposób jak zdjęć lotniczych w polskiej archeologii, a więc pobieżnie i bez wnikliwej analizy ich przydatności ani procesów powstawania tych pośrednich źródeł o przeszłości ${ }^{98}$.

W niniejszym artykule autor starał się wykazać nie tylko wysoki stopień subiektywizacji produktów skaningu laserowego, lecz także konieczność archeologicznego nadzoru nad każdym etapem poboru i obróbki danych. Dopóki prowadzący studia nad przeszłością, pragnący stosować we własnych badaniach dane ALS, nie zaczną eksplorować ich głębi oraz skomplikowanych procesów obróbki, dopóty olbrzymi potencjał prospekcyjny metody będzie wykorzystany jedynie w niewielkim zakresie. Co więcej, żadna firma geodezyjna nie zaoferuje archeologom takich efektów, jakie można uzyskać dzięki świadomemu, autorskiemu przetwarzaniu danych oraz indywidualnemu traktowaniu produktów lidarowych, przez stosowanie opracowanych specjalnie dla celów archeologicznych narzędzi analitycznych, metod wizualizacji danych oraz algorytmów przetwarzających chmurę punktów, modele numeryczne oraz ich pochodne. Jeżeli tak się nie stanie, to wyniki badań z powodu znaczącej redukcji informacji będą dalekie od satysfakcjonujących dla badaczy (niewykorzystujących pełnego potencjału metody) nierozpoznanych zasobów dziedzictwa (a przez to nieobjętych ochroną konserwatorską) oraz dla świadomego w tym zakresie podatnika.

\section{BIBLIOGRAFIA}

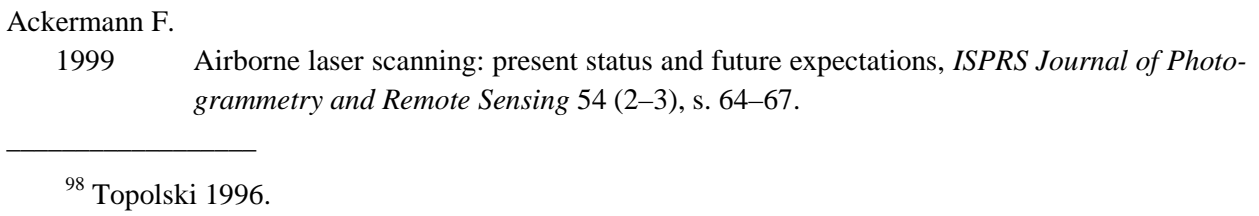

${ }^{98}$ Topolski 1996. 
American Society for Photogrammetry and Remote Sensing

2012 LAS Specification. Version 1.4-R12, Bathesda.

Bale J.B., Durland R.E., Ebert J.I., Goehring D.R., Parsons J.J., Strandberg C.H., Whittlesey J.J.

1975 People: Past and Present [w:] Manual of Remote Sensing, vol. II: Interpretation and Applications, red. L.W. Bowden, Falls Church, s. 1999-2060.

Budziszewski J., Wysocki J.

2012 Nowe możliwości detekcji materialnych śladów historii terenów leśnych - lotnicze skanowanie laserowe (LiDAR) [w:] Archaeologia Hereditas. Konserwacja zapobiegawcza środowiska 1, red. Z. Kobyliński, J. Wysocki, Warszawa-Zielona Góra, s. 117-126.

Bofinger J., Hesse R.

2011 As far as the laser can reach...: Laminar analysis of LiDAR detected structures as a powerful instrument for archaeological heritage management in Baden-Wurttemberg, Germany [w:] Remote Sensing for Archaeological Heritage Management. EAC Occasional Paper No. 5, red. D.C. Cowley, Bruxelles, s. 161-172.

Ciołkosz A., Miszalski J., Olędzki J.R.

1999 Interpretacja zdjęć lotniczych, Warszawa.

Challis K.

2006 Airborne laser altimetry in alleviated landscapes, Archaeological Prospection 13, 2, s. $103-127$.

Cowley D.C., Opitz R.S. (red.)

2012 Interpreting Archaeological Topography: Lasers, 3D Data, Observation, Visualisation and Applications, Oxford.

Crawford O.G.S.

1929 Air-Photography for Archaeologists, London.

Crawshaw A.

1995 Oblique Aerial Photography - Aircraft, Cameras and Films [w:] Luftbildarchaeologie in Ost- und Mitteleuropa. Forschungen zur Archaeologie im Land Brandenburg 3, red. J. Kunnow, Potsdam, s. 67-76.

Crutchley S., Crow P.

2009 The Light Fantastic: Using airborne laser scanning in archaeological survey, Swindon.

Devereux B., Amable G., Crow P., Cliff A.

2005 The potential of airborne lidar for detection of archaeological features under woodland canopies, Antiquity 79, s. 648-660.

Ducic V., Hollaus M., Ullrich A., Wagner W., Melzer Th.

2006 3D vegetation mapping and classification using full-waveform laser scanning [w:] 3-D Remote Sensing in Forestry, red. T. Koukal, W. Schneider, Vienna, s. 211-218.

Doneus M., Briese C.

2006 Digital terrain modelling for archaeological interpretation within forested areas using full-waveform laserscanning [w:] The 7th International Symposium on Virtual Reality, Archaeology and Cultural Heritage VAST 2006, red. M. Ioannides, D. Arnold, F. Niccolucci, K. Mania, Graz, s. 155-162.

Doneus M., Briese C.

2011 Airborne Laser Scanning in forested areas - potential and limitations of an archaeological prospection technique [w:] Remote Sensing for Archaeological Heritage Management. EAC Occasional Paper No. 5, red. D.C. Cowley, Bruxelles, s. 59-76.

Doneus M., Briese C., Fera M., Janner M.

2008 Archaeological prospection of forested areas using full-waveform airborne laser scanning, Journal of Archaeological Science 35, s. 882-893. 
Doneus M., Doneus N., Briese C., Pregesbauer M., Mandlburger G., Verhoeven G.

2013 Airborne Laser Bathymetry - detecting and recording submerged archaeological sites from the air, Journal of Archaeological Science 40, s. 2136-2151.

Engel M., Iwanicki P., Iwanowska G., Sobczak C.

2013 Grodziska Jaćwieży w perspektywie badań Działu Archeologii Bałtów Państwowego Muzeum Archeologicznego w Warszawie [w:] Archaeologica Hereditas. Grodziska Warmii i Mazur. 1. Stan wiedzy i perspektywy badawcze, tom 2, red. Z. Kobyliński, Warszawa-Zielona Góra, s. 45-64.

Hesse R.

2010 LiDAR-derived Local Relief Models - a new tool for archaeological prospection, Archaeological Prospection 17 (2), s. 67-72.

Holden N., Horne P., Bewley R.H.

2002 High-resolution digital airborne mapping and archaeology [w:] Aerial Archaeology: Developing Future Practice, red. R.H. Bewley, W. Rączkowski, Amsterdam, s. $173-180$.

Hug C., Ullrich A., Grimm A.

2004 Litemapper-5600 - A Waveform-Digitizing LiDAR Terrain and Vegetation Mapping System [w:] Laser-Scanners for Forest and Landscape Assessment, International Archives of Photogrammetry and Remote Sensing, 36-8/W2, red. M. Thies, B. Koch, H. Spiecker, H. Weinacker, s. 24-29.

Jenkins L.G.

2006 Key drivers in determining LiDAR sensor selection [w:] Proceedings of ISPRS Commission VII Mid-Symposium "Remote Sensing: From Pixels to Processes", red. N. Kerle, A. Skidmore, Enschede, s. 342-357.

Kundzierewicz T.

2010 MGGP Aero ma LiDAR, Geodeta. Magazyn geoinformacyjny 2 (177), s. 20-23.

Kobyliński Z., Borowski M., Budziszewski J., Herbich T., Kobyliński Ł., Sławik Ł., Wach D., Wysocki J., Jaszewska A.

2012 Kompleksowe, niedestrukcyjne rozpoznanie zasobów archeologicznych Starego Kraju w województwie lubuskim, Archeologia Środkowego Nadodrza 9, s. 11-42.

Kokalj Z., Zakšek K., Oštir K.

2012 Visualizations of lidar derived relief models [w:] Interpreting Archaeological Topography: Lasers, 3D Data, Observation, Visualisation and Applications, red. D.C. Cowley, R.S. Opitz, Oxford, s. 100-114.

Kraus K.

2004 Photogrammetrie. Band1. Geometrische Informationen aus Photographien und Laserscanneraufnahmen. 7., vollständig bearbeitete und er weiterte Auflage, Berlin-New York.

Miałdun. J.

2005 Wymiar fraktalny zobrazowań teledetekcyjnych krajobrazu ekologicznego, poddanego antropopresji [w:] Biskupin... i co dalej?, red. J. Nowakowski, A. Prinke, W. Rączkowski, Poznań, s. 109-116.

Miller G.S.P.

1994 Efficient Algorithms for Local and Global Accessibility Shading [w:] Proceedings of the 21th Annual Conference on Computer Graphics and Interactive Techniques, SIGGRAPH 1994, s. 319-326. 
Orlicka-Jasnoch J.

2012 Inwentaryzacja wybranych cmentarzysk kurhanowych ludności kultury łużyckiej z terenu województwa lubuskiego przy pomocy lotniczego skaningu laserowego (LiDAR), Archeologia Środkowego Nadodrza 9, s. 53-80.

Powlesland D.

1999 The Heslerton Parish Project. An integrated multi-sensor approach to the archaeological study of Eastern Yorkshire, England [w:] Ciclo di Lezioni sulla ricerca applicata in archeologia: Remote sensing in archaeology, red. S. Campana, M. Forte, Firenze, s. 233-256.

Rączkowski W.

2002a Beyond the Technology: Do We Need "Meta-Aerial Archaeology"? [w:] Aerial Archaeology: Developing Future Practice, red. R.H. Bewley, W. Rączkowski, Amsterdam, s. 311-327.

2002b Archeologia lotnicza. Metoda wobec teorii, Poznań.

Rusinkiewicz S., Burns M., DeCarlo D.

2006 Exaggerated shading for depicting shape and detail, ACM Transactions on Graphics 25 (3), s. 1199-1205.

Schiffer M.B.

1987 Formation processes of the archaeological record, Albuquerque.

Shaw R., Corns A.

2011 High resolution LiDAR specifically for archaeology: are we fully exploiting this valuable resource? [w:] Remote Sensing for Archaeological Heritage Management, red. D.C. Cowley, Bruxelles, s. 77-86.

Shell C., Roughley C.

2004 Exploring the Loughcrew landscape: a new airborne approach, Archaeology Ireland 18/2 (68), s. 22-25.

Sittler B.

2004 Revealing historical landscapes by using airborne laser scanning, a 3-d model of ridge and furrow in forests near Rastatt, Germany [w:] Laser-Scanners for Forest and Landscape Assessment, International Archives of Photogrammetry and Remote Sensing, 36-8/W2, red. M. Thies, B. Koch, H. Spiecker, H. Weinacker, s. 258-261.

Sławik Ł., Zapłata R.

2010 Lidar zmienia archeologię, Geodeta. Magazyn geoinformacyjny 10 (185), s. 66-68.

Topolski J.

1996 Jak się pisze i rozumie historię: tajemnice narracji historycznej, Warszawa.

Urbańczyk P.

1981 O możliwościach poznawczych archeologii, Przegląd archeologiczny 29, s. 5-52.

Wagner W., Ullrich A., Ducic V., Melzer T., Studnicka N.

2006 Gaussian decomposition and calibration of a novel small-footprint full-waveform digitising airborne laser scanner, ISPRS Journal of Photogrammetry and Remote Sensing, 60 (2), s. 100-112.

Wehr A., Lohr U.

1999 Airborne laser scanning - an introduction and overview, ISPRS Journal of Photogrammetry and Remote Sensing 54 (2-3), s. 68-82.

Wilson D.R.

1975 Photographic techniques in the air [w:] Aerial Reconnaissance for Archaeology, red. D.R. Wilson, London, s. 12-31.

Wilson D.R.

2000 Air Photo Interpretation for Archaeologists, Stroud. 
Wyczółkowski M., Szal M., Kupryjanowicz M., Smolska E.

2013 Kompleks osadniczy w Poganowie, pow. kętrzyński, stanowisko IV: wstępne wyniki badań interdyscyplinarnych [w:] Archaeologica Hereditas. Grodziska Warmii i Mazur. 1. Stan wiedzy i perspektywy badawcze, tom 2, red. Z. Kobyliński, Warszawa-Zielona Góra, s. 45-64.

Zakšek K., Oštir K., Kokalj Z.

2011 Sky-view factor as a relief visualization technique, Remote Sensing 3, s. 398-415.

Żuk L.

2005 W poszukiwaniu salomonowego rozwiązania, czyli o tym, kto powinien interpretować zdjęcia lotnicze - słów kilka [w:] Biskupin... i co dalej?, red. J. Nowakowski, A. Prinke, W. Rączkowski, Poznań, s. 125-144.

\section{AIRBORNE LASER SCANNING WITHIN POLISH ARCHAEOLOGY. IS THE METHOD'S POTENTIAL BEING FULLY EXPLOITED?}

\section{S u m m a r y}

The aim of the article is to introduce the use of ALS in archaeology by recognising the potential of scanning and emphasising the level of subjectivity of generated data. Possibilities for analysis and interpretation have been shown herein, as well as ways to improve the efficiency of analyses. Processes of reduction of information about the past, characteristic of the LiDAR data applications, have been identified, and solutions aiming to reduce these processes suggested.

The author assumes that, due to increasing interest in applications of the method in Polish archaeology it would be worth presenting both positive and negative aspects of the use of LiDAR data. Critical analysis of the formation, processing and interpretation procedures of scanning products aims to build awareness of the need to explore the full potential of ALS. This would only be possible if the traditional conception of spatial studies was rejected, while subjectivity of data taken into account. It would also require focusing on the procedure of the formation of these specific indirect sources. Otherwise, either archaeologists, conservation services, or all other, primary or secondary, recipients of the results of LiDAR prospection will be given strongly limited and reduced data of archaeological heritage. Aspects of data acquisition (e.g. adopted measurement methodology and physical capability of scanners) and methods of processing (e.g. algorithms related to the classification of the point cloud, joining the ranks of scanning, filtering data for generating DTM and DSM, and visualization of the secondary products), as described in the text, seem extremely important for the study of the past, and used efficiently, with the scanning parameters set for archaeological purposes (to some extent), would allow for limiting the reduction of information, typical in the procedure of LiDAR data use. It has been shown that, although each stage of the processing, analysis and interpretation of data causes losses, it depends on individual researchers how they might be reduced with adapting as many available tools and solutions as possible. Omission or no control over any of the described data processing stages may in fact cause irreversible and negative effects on heritage its recognition. Attention should be also paid to 
the unusual proximity of the interpretation of the products of ALS and aerial photographs. Experience gained from the analysis of aerial photographs helps to minimize the loss of information during data interpretation. Being more widespread in European archaeology, LiDAR has become more popular also in Poland. However, there is a threat that national archaeology, enthusiastic about the novelty of ALS, may greet it with insufficient criticism. It has been emphasised in the article that when treating ALS as a "perfect" prospection method one may not notice subjectivity of collected data, complicated methods of their processing, as well as aspects considering generalization and representation of reality. There are numerous similarities between LiDAR images and aerial photography, such as subjectivity of data, or an analogous method of obtaining it, thus attention was drawn to the fact that ALS should not be treated in a complementary manner as the aerial photography within Polish archaeology - superficially and without a thorough analysis of its products, indirect sources of the past, in terms of their suitability or of processes in which they were created. In the article, not only a high degree of subjectivity of laser scanning products has been pointed at, but also the need for archaeological supervision over all stages of collecting and processing data has been suggested. As long as in the studies of the past researchers who wish to use ALS data in their studies will not explore its depths and complexity of processing, a huge prospection potential of the method will be used only to a limited extent.

Moreover, no geodetic company will offer such results, as might be obtained through conscientious data processing and individual treatment of LiDAR products by archaeologists themselves, when using tools, data visualization methods and algorithms of point cloud, digital models, and secondary products, processing developed especially for the purpose of archaeology.

Translated by Lucyna Leśniak 